\title{
Review \\ Elicitor and Receptor Molecules: Orchestrators of Plant Defense and Immunity
}

\author{
Nurul Azmina Abdul Malik, Ilakiya Sharanee Kumar(i) and Kalaivani Nadarajah *(1) \\ Department of Biological Sciences and Biotechnology, Faculty of Science and Technology, \\ Universiti Kebangsaan Malaysia, 43600 Bangi, Selangor, Malaysia; azmina_malik93@yahoo.com (N.A.A.M.); \\ ilakiya95sharanee@gmail.com (I.S.K.) \\ * Correspondence: vani@ukm.edu.my
}

Received: 26 November 2019; Accepted: 13 January 2020; Published: 31 January 2020

\begin{abstract}
Pathogen-associated molecular patterns (PAMPs), microbe-associated molecular patterns (MAMPs), herbivore-associated molecular patterns (HAMPs), and damage-associated molecular patterns (DAMPs) are molecules produced by microorganisms and insects in the event of infection, microbial priming, and insect predation. These molecules are then recognized by receptor molecules on or within the plant, which activates the defense signaling pathways, resulting in plant's ability to overcome pathogenic invasion, induce systemic resistance, and protect against insect predation and damage. These small molecular motifs are conserved in all organisms. Fungi, bacteria, and insects have their own specific molecular patterns that induce defenses in plants. Most of the molecular patterns are either present as part of the pathogen's structure or exudates (in bacteria and fungi), or insect saliva and honeydew. Since biotic stresses such as pathogens and insects can impair crop yield and production, understanding the interaction between these organisms and the host via the elicitor-receptor interaction is essential to equip us with the knowledge necessary to design durable resistance in plants. In addition, it is also important to look into the role played by beneficial microbes and synthetic elicitors in activating plants' defense and protection against disease and predation. This review addresses receptors, elicitors, and the receptor-elicitor interactions where these components in fungi, bacteria, and insects will be elaborated, giving special emphasis to the molecules, responses, and mechanisms at play, variations between organisms where applicable, and applications and prospects.
\end{abstract}

Keywords: plant defense systems; SAR; ISR; pathogen-associated molecular patterns (PAMPs); microbe-associated molecular patterns (MAMPs); herbivory-associated molecular patterns (HAMPs); damage-associated molecular patterns (DAMPs); plant pattern recognition receptors (PRRs); receptor molecules

\section{Introduction}

Plants are constantly threatened by an array of biotic stresses in their natural environment. Since plants are primary producers, they are at the bottom of most food chains and are prone to invasion or infection by bacteria, fungi, insects, and herbivores. Being sessile, they are compelled to defend themselves against a plethora of unavoidable stresses [1,2]. Although plants do not have an immune system as advanced as animals, plants are able to display resistance toward the diseases and damage caused by these organisms by relying on the innate immunity of cells and systemic signaling from the site of infection [3-5]. Infiltration of a host can happen either through stomata (natural opening), physical injuries, or direct penetration of the plant surfaces [6]. This two-way interaction involves the recognition of host invasion and manipulation of host biology to bring about the 
colonization of host or result in cellular damage [7-10]. Therefore, a successful plant defense mechanism should inhibit organismal infection, and limit insect and herbivore damage to the whole plant.

The physical barrier in plants serves as first line of defense. This structural defense prevents pathogens and predators from invading the plant [11]. When infected, plants are able to recognize the changes in the cuticle, prompting activation of the defense responses [12]. Other mechanisms are activated when the immune responses in plants are induced due to infiltrations of either herbivores or pathogens. When pathogens and insects breach the first line of defense, it initiates a second line of defense that destroys the invading disease and pest by reducing structural damage beyond the site of infection and tissue damage. The second line of defense system is enhanced with the ability of plants to recognize certain pathogens and insects through their secretomes and other molecular patterns. These molecules interact with the plant surface, which amplifies the signals received through the transmission of plant signal molecules that induce signal transduction cascades and activate defense and resistance genes in resistant varieties, while the susceptible lines are overcome by the pathogens, insects, and herbivores [13,14]. Pathogens that infect the plants use different mechanisms based on their lifestyles that can either be biotrophic, necrotrophic, or hemibiotrophic $[15,16]$. While biotrophic pathogens feed off living tissue, the necrotrophic live off the dead, and the hemibiotrophic combine both strategies [17-19]. The plant too is divided into two systems based on its genetic basis of qualitative resistance (monogenic resistance) and quantitative resistance (polygenic resistance) [20]. The plant then reacts at the molecular level to invasion by the (i) non-host response, and (ii) host response depending on molecules secreted by both players [21,22]. As biotic stresses include insects, nematodes, and other hebivorous organisms, a breach of host defense provides for a different array of chemicals secretomes that reacts with the host and elicits a response that is mostly similar to what has been reported with pathogenic and non-pathogenic organisms.

Therefore, in this review, we will examine the roles played by elicitors, receptors, their interaction, and pathways activated in surmounting defense responses in hosts. These reactions involve responses to pathogens, non-pathogens, herbivores, and chemical signals. The existing gap in information and the potential applications of the knowledge acquired from this systematic review have been further elaborated.

\section{Plant's Immune Response: Key Components}

To begin elucidation of the role of receptors and elicitors in defense, we first need to understand the immune system in plant systems. Plant immune responses can be divided into plant innate and plant-induced immunity. In both these immune systems, receptor and effector molecules play a crucial role in its activation and execution.

\subsection{Plant Innate Immunity: Pre-Existing Defense}

Plant innate immunity is composed of pathogen-associated molecular patterns (PAMP)-triggered immunity (PTI) followed by effector-triggered immunity (ETI), which perceives and protects plants from threatening pathogens [23-26]. Unlike an animal's adaptive immune system, a plant's innate immune system relies on pre-existing receptor molecules in the cells. Activation of the plant's innate immunity is through the specific perception and recognition of PAMPs or microbe-associated molecular patterns (MAMPs) by pattern recognition receptors (PRRs) in plants (non-host resistance) or through identification by a resistance $(\mathrm{R})$ protein-mediated process against race-specific effector molecules of pathogens (host resistance) [27,28]. In the case of non-host resistance, a particular plant can be resistant to different kinds of pathogens, whilst the same pathogens may infect other plant systems. This is a process initiated by the specific recognition of pathogen molecules called MAMPs by PRR-type membrane receptor proteins. In the first phase of plant innate immunity, PTI stops the colonization of pathogens after their PAMPs are recognized by PRRs in plants. PAMPs are evolutionarily conserved pathogen-derived molecules that constitute portions of fungal cell walls, structural components of pathogens, or flagellum [29]. Several PAMPs can be perceived by numerous 
plant species, although this is dependent on the plant species specificity and effectiveness [28-30]. Nonetheless, some PAMPs could only be recognized by a limited number of plant species receptor molecules [31-37]. PAMPs, herbivory-associated molecular patterns (HAMPs), and damage-associated molecular patterns (DAMPs) that are originally called endogenous elicitors are also referred to as MAMPs [38]. The recognition of MAMPs at the molecular level results in PAMP-triggered immunity (PTI), which causes reactive oxygen species (ROS) production, the activation of mitogen-activated protein kinases (MAPK), $\mathrm{Ca}^{2+}$ signaling, and ultimately transcriptional reprogramming $[39,40]$.

There are various types of receptor molecules present in plants. The efficacy of these receptors are amazing, considering that with one receptor, a plant can recognize a complete taxonomic group that features a particular PAMP. For example, flagellin receptor FLS2 (flg22) enables the plant to recognize all mobile flagellated bacteria. However, it is possible for pathogens to avoid plant immunity through the mutation or deletion of these molecular patterns. A mutation in plants that affects the activity of PAMPs' recognition causes the plants to be more susceptible to adapted pathogens and allows some disease development by non-adapting pathogens. Ve1 is an example of a plant receptor molecule in tomato, which binds to the Ave1 elicitor molecule from fungi. Ve1 can also be introduced as the PRR or $\mathrm{R}$ protein where the Ave1 peptide is referred to as the effector acting as MAMP [41-43].

Receptor-like kinases (RLKs) are types of PRRs located at transmembrane that possess extracellular domains that are essential in transmitting information from external stimuli by recognizing the ligands $[6,44,45]$. The RLK-mediated signal transmission of defense against pathogens responds to treatment with elicitors, pathogens, and signal molecules produced during biotic responses. The responses of RLKs are often dependent on specific ligands and pathogens. For instance, the $S$ domain RLK (SFR1) is induced by bacteria and wounding, RLK3 is induced by oxidative stress and salicylic acid (SA), and potato receptor kinase (StPRKs)are induced by cell wall-degrading enzymes, short oligogalacturonides, and pathogen attack [46-48]. Further, wall-associated kinases (WAK) are induced by pathogens, SA, and cell wall pectin [49]. Some of these kinases have been identified as $R$ genes. Recently a leucine-rich repeat (LRR) receptor was identified with the ability to bind bacterial flagellin, resulting in the activation of the defense pathway. These RLPs or RLKs activate specific plant defensive responses following their recognition [28]. While direct receptor-elicitor interaction has been demonstrated (as in the flagellin-FLS2 interaction), the complexity of this interaction still lacks understanding. Examples of receptor and elicitor molecules will be discussed in greater depth in the following sessions.

\subsection{Plant-Induced Immunity: Effector Activated System}

Equally important is the plant-induced immunity where signaling molecules activate the defense response to protect plant tissue from further damage from biotic or abiotic stresses [50-52]. In contrast to PTI, ETI involves effector molecules instead of PAMPs, and it is different from PAMPs, where effectors act as indicators of potential pathogens. Virulence factors from the pathogens are secreted into the plants and act as effector molecules. $\mathrm{R}$ proteins in the plants will identify the effectors to activate ETI [25-27]. After the R proteins in plants recognize its corresponding effectors, the plant immediately activates its immune responses through the induction of ETI [53]. ETI is induced in phase two of plant innate immunity. An example of the effector- $R$ gene model in plant pathogen interaction can be seen in the interaction between coiled-coil, nucleotide binding site and leucine rich repeats (CC-NBS-LRR) of the Pi-ta receptor in rice and with the AvrPita effector of Magnaporthe grisea [54].

Most often when bacteria invade plants, EFR receptors that act as PRRs will detect the presence of the elongation factor (EF-Tu) elicitor molecules from the bacteria, which then triggers the immune system in plants. This form of immunity occurs in the cells' post-R protein perception of effector proteins and the elicitation of oxidative burst, hormone accumulation, MAPK activation, antimicrobial production, and pathogenesis-related protein (PR protein) expression in response to the invasion [11,28,55-57]. The initiation of ETI results in the death of cells in the infected area and thus prevents infection from spreading to other parts of the plant, causing hypersensitive response 
(HR) [28], which results in programmed cell death (PCD) [58]. When the plant survives the infection in one site, it often develops increased resistance to subsequent attacks throughout the plant and enjoys protection against a wide range of pathogenic species. This phenomenon is known as systemic acquired resistance (SAR), where it is transmitted through the phloem to other parts of the plant via signal molecules, resulting in increased resistance throughout the plant $[14,28,59]$.

Several examples of signaling molecules that are induced by pathogenic infection include SA, methyl salicylate, jasmonate (JA), and ethylene (ET). SA and ET/JA-mediated signaling pathways play a major role in plant resistance toward pathogens [60]. This results in higher levels of SA and its methyl ester, thus causing the production of PR proteins, including chitinases and other hydrolytic enzymes. Besides being an important factor in SAR, SA also plays a significant regulatory role in local HR against various pathogens. Methyl-SA [61], a methylated form of SA, is produced once the cell has been infected by the pathogen. This volatile SAR-inducing molecule travels to other parts of the plant through the plasmodesmata [62-64]. Fu et al. (2012) state that when SA is elevated at the area of infection, it will bind to the low-affinity binding receptor NPR3 (Nonexpressor of PR Genes 3) and cause the degeneration of cell-death suppressor NPR1, which subsequently results in HR [65]. SA binds NPR4, a high-affinity receptor molecule in the cell to prevent the deterioration of NPR1 and saves the cell [65]. Similarly, NPR1 also takes part in SA and JA dependent defense pathways, thereby promoting appropriate immune response within the plant [66]. It has been shown that JA acts through a conserved signaling mechanism that has close resemblance to that described for other plant hormones such as auxin and gibberellins $[67,68]$.

It has been shown that PAMPs such as lipopolysaccharides can induce SAR [69]. This system provides specific resistance to pathogens through the interaction of plant resistance $(R)$ gene products and pathogen-derived avirulent gene products. A plant's response to PAMPs can be viewed as an expression of basal resistance, since most of plant's immunity is considered innate. Mitogen-activated protein kinase serves as a signal transducer that perceives the signal from the elicitor receptor interaction and thence amplifies and transmits the signal to distal tissues to activate the defense response systemically [70]. Signaling cascades generated by this response are responsible for the activation of plant's innate immune system [27]. The above processes are in place to block the advancement of biotrophic organisms, which arrest the spread of infection to other host tissues through the production of ROS and nirogen dioxide $\left(\mathrm{NO}_{2}\right)$ [20,71]. The necrotrophic pathogens on the other hand use the plant cell wall as the first line of defense, where they play a role in the integrity sensory system, leading to the activation of defense response and elevated levels of JA and ET [19]. The SA signaling pathway controls plant defense mechanisms against biotrophic pathogens while the ET/JA pathways are usually needed for plant resistance toward necrotrophic pathogens and herbivorous pests [72,73]. On the other hand, when an interaction occurs between plants and non-pathogenic microorganisms, systemic resistance [74] is activated. These microorganisms activate signaling pathways involving JA and ET, which trigger induced systemic resistance (ISR) throughout the plant. The colonization of these microorganisms initiates a signaling cascade throughout the plant and activates protective mechanisms. ISR results in enhanced resistance against pathogen attack rather than activating immediate defensive measures in the plant. Lipopolysaccharides (LPS) triggered by rhizobacteria are an example of molecules that are able to activate induced systemic resistance [74] against subsequent infections without the need for the accumulation of PR protein and phytoalexins $[43,75]$.

\section{Model of Interaction between Effector and $R$ genes in Plant Immunity}

\subsection{The Guard Hypothesis}

There have been other models that have materialized to explain the recognition process between a receptor molecule and elicitors besides the general recognition model. Amongst these models, the "Guard hypothesis" suggest that the R protein detects changes by the effector to the guard (host) 
protein. An example at hand for this model is the targeting of the RIN4 protein by the AvrRpm1 and Avrpt2 effectors, which cleaves the RIN4 in Arabidopsis, leading to its recognition by the R protein $[76,77]$.

\subsection{The Decoy Protein Hypothesis}

Unlike the above, the "decoy protein" hypothesis is built on the concept that this decoy protein is able to mimic the pathogen effector target and restrict infection but has no direct role in immunity [77]. A good example for this model would be the decoying method of extracellular Protein-6 (Ecp6) produced by Cladosporium fulvum while infecting tomato that mimicks the chitin-binding capacity of the receptor to surpress chitin recognition by the host [78]. Based on the evolutionary basis upon which this hypothesis is built, this protein increases or decreases its affinity for effectors based on the presence or absence of the $R$ gene $[79,80]$.

\subsection{The Zig-Zag Model}

Finally, we approach the currently accepted zig-zag model, which basically involves interaction between the pathogen and the host. However, some scientists are of the opinion that this concept has oversimplified a complex process such as a pathosystem, while others question the terminologies and the specificity of the terms used [81,82]. However, there were some concerns highlighted with regard to this model. They are as follows. (1) The model does not include DAMPs in its prediction. (2) The model discounts the involvement of the environment in the interaction. (3) The model does not look into the possibility that the process may be random and not structured. (4) The model does not provide a timescale for the gain or loss of effectors. (5) The model does not provide details on the population context by which this gain or loss of effector takes place. (6) Finally, it lacks a qualitative model on the effects of miRNAs on the response of PTI and ETI (e.g., miR393, miR482) [8]. Therefore, while as a concept the zig-zag model does represent the interaction closely, the players and contributing factors need to be adjusted according to the pathosystem studied.

\subsection{The Invasion and Multicomponent Model}

In recent years, two more models have been put forth: the invasion and the multicomponent model. The invasion model is built on the zig-zag model and improves on its limitations. This model is like the zig-zag model except that the definition of the immunogenic molecules are different [61]. In this model, the molecules are seen as entities that play a role beyond just pathogenicity, therefore opening the molecule up to the effect of evolution and affecting the way these molecules interact and influence the pathogen-host fitness. The multicompent model, on the other hand, is different from other models where the $R$ genes and effectors are described as independent where all plant pathogen-related information should be utilized to design techniques in plant breeding for resistance. This model is established on two main components: activation and modulation [83], which is further divided into (1) interaction between principle components (virulence targets and plant metabolism), (2) $R$ gene activation of PRR-triggered signaling (PTS), (3) metabolic changes resulting in feedback regulation triggering hormone-tempered resistance (HTR), and (4) modulation of the resistance stage where PTS and the HTR together control resistance based on the pathogen's lifestyle. However, at this juncture, we would like to state that these two recent models do not discredit the zig-zag model but highlight perspectives to be considered to provide a holistic view of plant immunity beyond molecular interaction.

\section{The Plant Defense Response: The Players and Pathways Involved}

The elicitor-receptor interaction triggers the pathway that sets the defense system in a plant into motion. A common early element of defense signaling is the modification of the ion permeability of the plasma membrane (Figure 1). Receptor molecule activation first stimulates the opening of ion channels across the membrane. Due to this, an influx of calcium ions into the plant cells occurs, which then activates reactive oxygen species (ROS) production in the cell. The accumulation of ROS around 
the location of proliferation has been reported in the fungal and bacterial pathogen infestation of plants [84]. The accumulation of ROS causes an oxidative burst that may act directly as a defense mechanism or signal the activation of other defenses [85]. These initial reactions are essential to initiate the signaling network that will activate all of the defense responses [86].

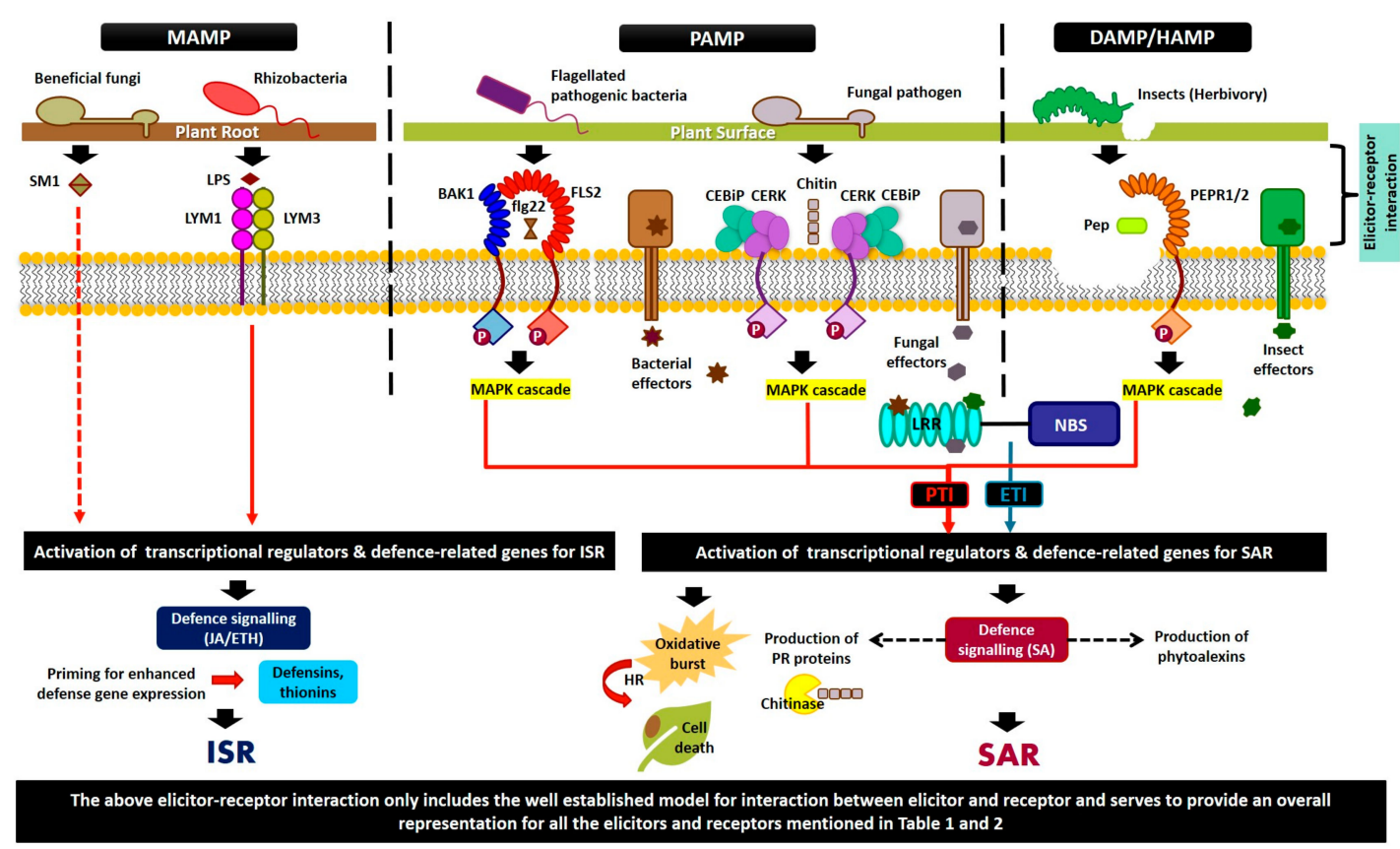

Figure 1. Pathogen-associated molecular patterns (PAMP)-triggered immunity (PTI) and effector-triggered immunity (ETI) for different types of molecular patterns produced by pathogenic and non-pathogenic microorganisms and insects (microbe-associated molecular patterns (MAMPs), damage-associated molecular patterns (DAMPs), and herbivore-associated molecular patterns (HAMPs). The well-established elicitor-receptor model for pathogenic fungus and bacteria, insects and non-pathogenic microbes are chitin elicitor binding protein/chitin elicitor receptor kinase (CEBIP/CERK), chitin, FLAGELLIN SENSITIVE2/BRI1-associated kinase (FLS2/BAK1), flg22, PEP receptor 1/2 (PEPR1/2), peptides (Pep), Lysin motif protein $\frac{1}{2}$ (LYM1/LYM2), LPS, and hydrophobin-like elicitor (SM1). Other examples of elicitors and receptors are provided in Tables 1 and 2.

PCD initiated by pathogen attack involves the expression of a set of genes that organize the dismantling of cellular components and the quick accumulation of toxic molecules, thus depriving the pathogens of nutrients and ultimately resulting in cell death [87]. As a result, the rest of the plant remains unaffected due to HR [88]. It provides resistance against pathogens and is often preceded by the rapid accumulation of ROS. This oxidative burst stimulates and contributes to cell death and other defense mechanisms. It may also act to kill the pathogens directly [89]. There are two phases in ROS production: the first phase is the rapid, transient, nonspecific ROS production, and the second phase occurs later, where the concentration of ROS is much higher than the first [90].

PR proteins are produced as a consequence of SAR, and these defense-related proteins are closely associated with pathogen infection. An assortment of hydrolytic enzymes such as glucanases, chitinases, and other hydrolases are induced by fungal invasion. Together with the formation of PR proteins, plants also produce some proteins that inhibit herbivorous insect digestion as part of the plant defense mechanism. Proteins that interfere with herbivore digestion are among the diverse components of plant defense responses induced by JA. For example, some legumes synthesize $\alpha$-amylase inhibitors that blocks the action of the starch-digesting enzyme $\alpha$-amylase [91]. Anti-digestive proteins such as protease inhibitors are found in legumes, tomatoes, and other plants, where they halt protease activities [92]. After entering the herbivores' digestive tract, the protease inhibitors obstruct protein digestion by binding tightly and specifically to the active site of the proteolytic enzymes. Insects that 
feed on plants containing protease inhibitors suffer reduced rates of growth and development. Plants that were transformed to accumulate increased levels of protease inhibitors suffered less damage from insect herbivores than untransformed control plants did [93].

Next, the synthesis of phytoalexins is initiated as a biochemical plant defense response. These molecules are considered to be the best-studied response of plants to bacterial and fungal invasion. Phytoalexins constitute a chemically complexed group of secondary metabolites with strong antimicrobial activity that accumulates around the site of infection and increases after pathogen attack. The production of phytoalexins is a regular mechanism of resistance toward pathogens in many plants. However, different plant families employ different types of secondary products as phytoalexins. For instance, isoflavonoids are common phytoalexins in leguminous plants such as soybean and alfalfa, whereas various sesquiterpenes are produced as phytoalexins, in solanaceous plants such as potato, tobacco, and tomato. Phytoalexins are generally undetectable in plants before infection, but they are synthesized very rapidly after pathogen attack. Experiments on genetically modified plants and pathogens have provided the first direct proof of phytoalexins' function in vivo. For example, control plants without transgenes are less resistant than tobacco with a transgene that catalyzes the biosynthesis of phenylpropanoid phytoalexin resveratrol, which results in augmented resistance toward fungal pathogens [94]. In other experiments, pathogens transformed with genes encoding phytoalexin-degrading enzymes were able to infect plants, which were normally resistant [95]. Through these series of events, the defense mechanism is initiated and the message is transmitted to distal tissues to protect the plants. However, for the immune system and defense signaling to function, two key players are required: the elicitor and the receptor molecules. There are two steps in the elicitor receptor ligand interaction which fits into the address-message hypothesis proposed for the activation of receptor by neuropeptides [96], where the first step is the binding of elicitor to the receptor, resulting in its activation through the formation of a ligand receptor complex that results in conformational change. The second step involves the regulation of the receptor, which results in the transmission of the information received via transmembrane signaling [97]. Besides, the physiological effects and binding feature of the agonist/antagonist pairs correspond with the address-message concept. In the following sections, we look into various elicitors and receptors that are involved in responses to pathogens and insect predators and are responsible for receipt and thence amplification and transduction of the signal leading to defense activation.

\section{The Elicitation of Defense: Elicitor Molecules, the Initiators of the Defense Cascade}

Elicitor molecules do not have a signature structure and are made up of molecules such as oligosaccharides, peptides, lipids, and proteins. They include molecules released from or produced by pathogens $[98,99]$ that provide information for plants to perceive and recognize signal from pathogens by cell surface-localized receptors, resulting in the activation of plant immunity [98]. One major research challenge in this area is the identification of receptors to elicitors, and to date, only a few receptors have been identified for specific elicitor molecules. Current reports have shown that plants are able to respond to the above array of elicitor molecules through the interaction with common elicitor motifs.

Elicitors in pathogens can be categorized into two categories: general elicitors and race-specific elicitors [100]. General elicitors are involved in the general resistance signaling pathways, while race-specific elicitors are associated with $\mathrm{R}$ gene-mediated signaling [101]. Elicitors that are capable of triggering defense in both non-host and host plants through the perceived presence of potential pathogens are known as general elicitors [41,102-106]. Most general elicitors are essentially present in pathogen cell walls as structural components e.g., glucan, chitin, flagellin, and lipopolysaccharides (LPS). Some general elicitors can only recognize a limited number of plants and are active only in specific hosts $[74,107,108]$. For instance, the oligosaccharides elicitors from M. grisea triggered phytoalexins synthesis in rice cells as the specific host and not in soybean cotyledon cells [107]. In contrast, $\beta$-glucan elicitors from Phytophthora sojae are able to activate defense responses in rice, 
soybean, and other non-hosts $[109,110]$. For example, a $75-k D a$ protein associated with the plasma membrane of Glycine max and Phaseolus vulgaris binds $\beta$-glucan elicitors from Phytophthora sp with high affinity. However, none of these proteins exhibit a signaling domain, suggesting that these $\beta$-glucan binding proteins may interact with other components to transduce the elicitor signal.

Meanwhile, race-specific elicitors play essential roles as virulence determinants [100]. These virulence determinants include harpins and avr gene products (see Table 1). This cultivar-specific (gene-for-gene) resistance can be determined by the pair of genes that complement each other between pathogen races and specific host cultivars [111]. The absence of either one of these genes in the interaction can result in disease [112-117]. In most plant pathogens, the initial elicitor and virulence determinant produced may be cell wall-degrading enzymes that facilitate infiltration. These enzymes provide the pathogen with nutrients and release pectic fragments that function as endogenous elicitors [108,118]. Elicitors are also produced in the leguminous-rhizobia interaction where the chemicals exuded by the plant will result in the recruitment of bacteria that orchestrate nodulation [119]. The lipo-chitooligosaccharides produced act as Nod factors and also provide evidence of the evolution of Nod factors from general elicitors $[98,119]$. Table 1 provides a list of elicitor molecules produced by bacteria, fungi, and insects.

\subsection{Fungal Elicitor Molecules and their Ability to Induce Defense Response}

An example of a fungal elicitor molecule is the chitooligosaccharide elicitor, chitin [28,59,120-125] (Table 1). Chitin is an important component of fungal pathogenicity, where pathogens with defects in chitin synthesis are significantly less virulent on susceptible hosts. Chitin, a polymer of $N$-acetyl-D-glucosamine, consists of (1-4)-linked 2-acetamido-2-deoxy- $\beta$-D-glucopyranose (GlcNAc) residues that are insoluble components of fungal cell walls [126]. It has been reported that the length of the $\mathrm{N}$-acetylchitooligosaccharides affects the chitin-induced signaling activity. This can be shown by a lower activity of $\mathrm{N}$-acetylchitooligosaccharides that is shorter than hexamers in activating defense response, where the highest induction of defense was seen with octaose and heptaose oligosaccharides ([GlcNAc] 7/8) in cultured-rice cells [127]. Chitin is recognized by plants, where it triggers a cascade of activities that leads to the elicitation of various defense responses which results in protection against fungal infections [37]. The expression of defense-regulating genes in rice suspension cells was induced by chitin [128-131] with increased resistance to rice blast [128]. In addition, chitin also induced ion efflux [132-134] 2013), the generation of ROS [128,135-137], increased levels of chitinases [138], higher levels of phytoalexins [139-141] and the induction of hypersensitivity in infected cells [126,128,142]. Chitinases that are commonly present in plants degrade chitin into soluble components [143] and thence trigger immunity. Furthermore, some toxins produced by pathogens are also able to function as elicitors at very low concentrations and elicit defense responses. For instance, the rice blast pathogen produces $\alpha$-picolinic acid, which is a toxin that can elicit HR and increase disease resistance in rice by activating hydrogen peroxide generation and cell death [144].

Ethylene-inducing xylanase (EIX) is another classic example of a fungal elicitor. As the name suggests, this elicitor is often associated with the biosynthesis of ethylene, which leads to the leakage of electrolytes, the expression of PR proteins, and sometimes the manifestation of a hypersensitive response in some plant species. The corresponding receptors for this elicitor, namely LeEix 1 and LeEix2, were identified in tomato [145] and were shown to work as a duo whereby LeEix1 attenuates the signals from LeEix2 by acting as a decoy receptor. Cerebroside is a type of sphingolipid-an important component of the phytopathogen's cell membrane-that demonstrates involvement in plant-pathogen interaction $[146,147]$. They are purported to induce the defense signal in rice and facilitate the synthesis of PR proteins and the production of $\mathrm{H}_{2} \mathrm{O}_{2}$ in tomato root tissues. In a study on Fusarium diseases, the induction of cerebrosides elevated the expression of PR proteins in tomato plants, although there was not any evidence of direct antifungal activity [147]. Further, plant MAMPs/PAMPs can also recognize $\beta$-1,3-glucan, which is another distinct type of fungal elicitor that constitutes the fungal cell wall [148]. The linear form of $\beta-1,3$-glucan known as laminarin (Lam) was shown to trigger 
defense-related responses in a wide number of plant species via the expression of ethylene-dependent and SA-dependent PR proteins [149]. Other types of fungal elicitors with corresponding plant systems are presented in Table 1 and Figure 1.

\subsection{Bacterial Elicitor Molecules and Their Ability to Induce Defense Response}

Bacterial pathogens are capable of producing distinct categories of virulence factors that avoid PTI, advance growth, and increase the disease-causing ability to the host [150]. The delivery of virulence factors into plants is the most important element in bacterial pathogenesis [151] where it targets PRRs, represses PTI, and allows colonization of the bacteria [27]. After successful colonization, the bacteria use their extracellular virulence factors such as enzymes that degrade the cell wall and permeate the cell walls of plants to obtain water and nutrient supplies [152]. Type-III secreted effector (T3E) is an example of a virulence factor that is injected into the plant cells during bacterial invasion. By injecting T3E into the plant cells, the bacteria can either repress the plant defense or increase bacterial fitness. However, resistance proteins in the plant cells are still able to detect secreted T3E, thus activating the second layer of immune response, i.e., ETI. The identification of T3E by the plant R proteins results in HR [153]. Different types of defense responses can be elicited in the plant depending on the level and method of elicitor interaction. For example, hairpin elicitor proteins from Erwinia amylovora activate HR when introduced to the plant intercellular space; however, when sprayed, they cause the initiation of SAR $[154,155]$.

Effectors released by the pathogen via T3SS can inhibit plant immunity and facilitate the colonization of the bacteria [156]. Plants can differentiate between the presence of microbes and pathogenesis patterns via the amplification of response to PAMPs by T3SS in bacteria $[157,158]$. LPS produced by Gram-positive and Gram-negative bacteria are capable of triggering plant immunity $[28,159]$ (Table 1). Almost all bacterial cell walls have peptidoglycan, which provides the bacteria with its shape and gives the bacteria its structure [160]. For this reason, both plants and animals have developed peptidoglycan perception systems in order for them to be able to detect the presence of bacteria [161,162]. In fact, peptidoglycan acts as bacterial elicitor molecule in Arabidopsis thaliana, rice, and tobacco, where it elicits defense [28,104,163-168]. Another study also stated that Arabidopsis cells are not as sensitive as rice cells in the induction of PCD when stimulated by the LPS. This shows that different plants respond differently to LPS [169]. Through these studies, it has been established that when plants are induced with peptidoglycan, the immune response is activated, resulting in responses such as the increase of cytoplasmic calcium concentration and the accumulation of ROS $[163,164]$.

Studies have reported that plants treated with LPS generate ROS [170,171] and express PR proteins as a consequence of the treatment $[172,173]$. Further, nitric oxide (NO) synthase was also induced when $A$. thaliana was treated with LPS, where NO plays a part in activating the defense genes and resistance against the pathogen [174]. In addition, LPS treatment has triggered SAR in many plant species [175-177]. The defense response is induced through the recognition of epitopes by different perception systems affected by LPS from different bacterial species [169,171,173,174,178-183].

Several studies have been conducted on the interaction between plants and flagellin. A study reported that flagellin-insensitive mutants were not responsive to bacteria as the FLS2 receptor (contains transmembrane, cytoplasmic ser/thr kinase, and extracellular leucine-rich repeats (LRR) domains) involved in the recognition of flagellin was defective [150]. Following the binding of FLS2 to flagellin, the FLS2 protein complex undergo dynamic changes induced through the perception of the 22-amino acid epitope of flagellin (flg22), which is known as detergent-resistant membranes (DRMs) [20,184]. This results in the heterodimerization between FLS2 and its co-receptor, BRI1-associated kinase (BAK1) [153]. Somatic embryogenesis receptor-like kinase (SERK) is involved in FLS2 signaling, and BAK1 is a SERK member [185]. BAK1 is a better co-receptor for FLS2 compared to EFR [185] and is involved in the late endosome, where it is needed for FLS2 accumulation [44]. In fact, there is a sequence change in the mutant alleles of FLS2, which reinforces the fact that this gene plays a role in the 
flagellin-insensitive phenotype. From previous studies, it was reported that two hydrophobic domains at the $\mathrm{N}$ terminus between amino acids 1-23 and 815-831 are the signal peptides of transmembrane domains [186]. The process starts when the PRRs in plants recognize the flagellin produced by virulent and avirulent bacteria and initiate the immune response in plants through the production of ROS and ethylene and the activation of defense-related genes [151]. So, here, flagellin acts as the general conserved elicitor that initially activates the immune response of the host [187] (Table 1 and Figure 1).

\subsection{Insect Elicitor Molecules: HAMPs and DAMPs vs. MAMPs}

In addition, plants can also recognize specific components of insect saliva during herbivory. A plant's response to damage by insect herbivores involves wound response and the recognition of certain insect-derived molecules [188-191]. Such insect-derived elicitor molecules can trigger signaling pathways, thereby initiating defense mechanisms in distant regions of the plants in anticipation of further damage. The herbivore-specific molecules that are secreted during insect feeding can be designated as herbivore-associated molecular patterns (HAMPs). These molecules participate in signaling and can induce defense reactions in plants. Other than components of oral secretion, these molecules include components of saliva and oviposition fluid [192]. Insect oral secretions have also developed into effectors that consist of specific proteins and chemicals that can inhibit the plant defense mechanisms. However, as time passes, some of the plants are able to overcome this inhibition when they have adapted themselves to recognize the molecules from the insect [193]. In other words, a lot of molecules in oral secretions can cause the plant to activate its defense response, involving enzymes such as glucose oxidase and $\beta$-glucosidase, peptides such as inceptin, and fatty acid conjugates such as volicitin [194].

One of the first types of elicitor identified in insect saliva was fatty acid-amino acid conjugates (FACs) or fatty acid amides [195] (Table 1). The well-studied FACs of Manduca sexta have a two-pronged approach where the volatiles produced can activate the defense response in a host whilst simultaneously attracting the predators of this caterpillar. Since this initial discovery, other types of elicitors have been identified where their specific elicitor molecule activity varies greatly among plant species [196]. Similarly, volicitin (N-(17-hydroxylinolenoyl)-L-glutamine) produced by Spodoptera exigua affected maize, which resulted in volatiles that functioned as attractants [195]. This chemical when applied to tobacco was shown to induce mitogen-activated protein kinase (MAPK), wound-induced protein kinase (WIPK), SA-induced protein kinase (SIPK), JA, SA, ethylene (ET), and JA-isoleucine conjugate (JA-Ile) [194]. The FACs produced induced the production of 7-epi-JA, which activates defense genes against insects [197]. In addition, inceptins and caeliferins in the oral secretions also activate defensive pathways to insects $[43,198]$. Furthermore, Tian et al. (2012) and Louis et al. (2013) reported on the induction of defense signaling in response to glucose oxidase (GOX) in the saliva of insects. The salivary component of $O$. nubilalis induces proteinase inhibitor 2 (PIN2) in maize and tomato $[199,200]$. However, there are some oral secretions that inhibit the defense pathway in plants. This has been reported in Spodoptera littoralis and Pieris brassicae where salivary secretions inhibited defense in order to enable larvae growth [201]. Therefore, these molecules can either activate or repress the plant defense responses [201,202], depending on which is leading the evolutionary process: the plant or the insect.

Some herbivorous insects may indirectly cause damage to plants, as these insects can generate damage-associated molecular patterns (DAMPs) that elicit a plant's immune response [193]. For aphids to be able to use their effector proteins to manipulate or interrupt any process in plants, the proteins need to be secreted into the plant during plant-aphid interaction $[43,203]$. Elicitor molecules derived from aphids or any organisms that are associated with aphids might be responsible for controlling the PTI-induced responses in plants. These organisms inhabit the aphid and are capable of producing proteins that activate plant defense [204]. To date, only a handful of effector proteins associated with aphids have been identified and proven to be involved in inducing or repressing defense responses [204]. For example, Mp10 is essential for aphid fertility. This effector protein can also alter SA and JA-signaling molecules in plants and activate defense $[205,206]$. 
In addition to saliva, the honey dew produced by insects can also interact with the plants' defense receptors [207]. These proteins sometimes carry bacterial proteins that include chaperones and flagellins that are produced by microbiota within the insect's gut [208]. In insects such as aphids, pathogenic organisms such as Pseudomonas syringae, Serratia marcescens, and Staphyloccocus sp are part of their gut microbiota [208,209]. These bacterial proteins trigger plant immunity and can lead to the activation or suppression of defense responses, depending on the insect species [204].

As seen in Figure 1, the elicitor molecules produced by each group of organisms are distinct to that specific group. The mechanism of interaction and the scope of effect elicited by these proteins are largely dependent on the type of elicitor molecule.

\subsection{Non-Pathogenic Elicitor Molecules: Inducers of Systemic Resistance}

Flagellin from the beneficial Pseudomonas putida WCS358 has been reported to induce systemic resistance against $P$. syringae in Arabidopsis [210]. Similarly, the LPS of certain Gram-negative bacteria have also been reported to induce systemic resistance. These tripartite amphipathic molecules with an immunologically active O-antigen side chain have induced ISR in Pseudomonas fluorescens pathosystems [210] and P. putida strains [210,211]. They have also been reported as effective ISR inducers in Burkholderia cepacia-Phytophthora nicotianeae interactions and Rhizobium elti G12-nematode infections of potato [177]. Further, siderophores produced by fluorescent Pseudomonas enable growth in iron-limiting environments [212]. Pyoverdines, a type of siderophores, behaves as a ISR elicitor [213,214]. WCS358 elicits ISR in Arabidopsis and tomato through siderophore $[210,215,216]$. SA is produced by some of these rhizobacteria that induce systemic resistance under iron-limiting conditions. Its role in the ISR elicitation process was demonstrated in the case of Pseudomonas aeruginosa KMPCH [217,218]. Nevertheless, several reports showed that SA production by other strains was not associated with ISR $[211,219]$. SA is also an intermediate in the biosynthesis of other siderophores such as pyochelin in P. aeruginosa [220]. P. aeruginosa 7NSK2-produced pyochelin is proposed to induce ISR in tomato [221,222].

Tri-N-alkylated benzylamine derivative (NABD) produced by P. putida BTP1 has ISR-inducing abilities [219]. Other researchers have reported the antibiotic properties of some Pseudomonas secretions such as pyocyanine and 2,4-diacetylphloroglucinol (DAPG), which induces systemic resistance $[215,223,224]$. Pyocyanine and pyochelin trigger ISR in P. aeruginosa 7NSK2-treated tomato [221]. P. fluorescens CHA0-produced DAPG stimulates ISR-mediated responses in Peronospora parasitica and Meloidogyne javanica-infected Arabidopsis and tomato $[215,225]$. In addition, biosurfactants such as rhamnolipids and lipopeptides produced by Pseudomonas and Bacillus were able to induce systemic resistance. This includes massetolide A, which protects tomato plants against Phytophthora infestans [226]. In another study, tomatoes overexpressing fengycins and surfactins from Bacillus subtilis 168 significantly induced resistance [227].

Other than the above-mentioned molecules, beneficial rhizobacteria produce exopolysaccharides [228] or N-acyl-L-homoserine lactone [229] as MAMPs. Trichoderma virens-produced hydrophobin-like elicitor $\mathrm{Sm} 1$ elicited ISR in maize. When cultivated with $S m 1$ mutant strains, maize showed either increased or reduced protection, indicating a role for this elicitor in systemic resistance [230]. A similar response was produced by Trichoderma. The disruption of the tex 1 gene responsible for peptaibol production results in significantly reduced ISR in cucumber against $P$. syringae [231]. Contrary to the above, alamethicin, a peptaibol, resulted in the cell death of $A$. thaliana, indicating that these molecules may retain some phytotoxic element on certain species [232]. Recently, harzianolide and pentyl-pyranone have also been implicated as secondary metabolites that have a role in induced systemic resistance [233].

\subsection{Non-Microbial Elicitors Molecules: Efficient Inducers of Defense}

Biotic elicitors have also been isolated from algae, shrimp, and other crustaceous materials. Chitin and chitosan derived from algae or crustaceous material have been shown to induce defense mechanisms in plants through the binding of receptor molecules found in the plants' plasma membrane $[234,235]$. Linear hepta- $\beta$-glucoside laminarin produced by brown algae elicits a defense in various plants species. A binding site has been identified for this elicitor molecule in rice and 
soybean [236-238]. These molecules, similar to pathogenic and non-pathogenic organisms, are able to mimic plant-pathogen response and activate SAR $[239,240]$. These non-microbial molecules successfully activate SA, JA, and systemin, leading to the activation and induction of systemic protection [241]. For example, in tomato, immediately after wounding by insects, prosystemin is synthesized, which then is proteolytically processed to systemin. Systemin binds to a cell surface receptor at the plasma membrane and activates defense. Chemical elicitors such as DL- $\beta$-aminobutyric acid (BABA) [242], 2,6-dichloro isonicotinic acid (INA) [243], benzo [1-3] thiadiazole (BTH) [240], and their derivatives are effective elicitors to induce the biosynthesis of plants.

It has been substantiated that BTH succeeded in inducing resistance to a lot of diseases, as it can be considered as a chemical that resembles SA [105]. For example, BTH and SA have been used as inducers in Brassice juncea (var. Rlm619), where it induces the production of enzymes such as peroxidase. It also prevents Alternaria brassicae from invading plants [244]. Moreover, BTH and humic acid (HA) in G. max minimized the risk of wilt disease and increased the growth rate of plants. The activity of oxidative enzymes is the highest when both elicitors, BTH and HA, are combined together [245]. These molecules are a good source for the exogenous induction of resistance in plant systems.

From the above elicitor systems, we can conclude that while there are a great variety of elicitors in the chemical and biological form, the downstream processes that lead to defense activation are similar. Most of these elicitors bind receptor molecules on the plant cell or interact within to elicit a defense response that results in ROS, HR, PCD, and the activation of resistance and defense-related genes in planta (Table 1; Figure 1).

Table 1. List of identified elicitor molecules of biotic stress agents in bacteria, fungi, insect, and synthetic molecules.

\begin{tabular}{|c|c|c|c|}
\hline Origin & Elicitor Molecule & Effects Shown in & References \\
\hline \multirow{16}{*}{ Bacteria } & Harpin (HrpZ) & Various plants & {$[28,246,247]$} \\
\hline & Flagellin & Most plants except rice (e.g., Arabidopsis) & {$[28,183]$} \\
\hline & Cold shock proteins & Solanaceae & [28] \\
\hline & Elongation factor (EF-Tu) & Brassicaceae & [28] \\
\hline & Lipopolysaccharides (LPS) & Arabidopsis, pepper, and tomato & [28] \\
\hline & Peptidoglycan & Arabidopsis and tobacco & [28] \\
\hline & Oligogalacturonides & Arabidopsis and tomato & [108] \\
\hline & Lipopeptides & Tomato & [248] \\
\hline & Dimethylsulfide & Maize and tobacco & [249] \\
\hline & Pseudobactin & Several plants & [214] \\
\hline & Type-III secreted effector (T3E) & Several plants & [153] \\
\hline & Tri-N-alkylated benzylamine derivative (NABD) & Bean & [219] \\
\hline & $\begin{array}{l}\text { 2,4-diacetylphloroglucinol } \\
\text { (DAPG) }\end{array}$ & Tomato, Arabidopsis & {$[211,219,220]$} \\
\hline & Pyocyanine and pyochelin & Tomato & [221] \\
\hline & Exopolysaccharides & Tobacco & [228] \\
\hline & $N$-acyl-L-homoserine lactone & Tomato & [229] \\
\hline \multirow{10}{*}{ Fungi } & B-glucans & Several plants (e.g., rice) & {$[28,250-253]$} \\
\hline & Chitin/chitosan & Arabidopsis, rice, tomato, and wheat & {$[28,120-124]$} \\
\hline & Cerebrosides A, C & Rice & {$[28,147]$} \\
\hline & Ergosterol & Grapevine, tomato, and tobacco & {$[28,254,255]$} \\
\hline & Xylanase & Tobacco and tomato & [28] \\
\hline & HR-inducing protein & Rice & [256-258] \\
\hline & PemG1 & Arabidopsis and rice & {$[259,260]$} \\
\hline & PebC1 & Tomato & [55] \\
\hline & Oligosaccharides & Rice & [107] \\
\hline & Ethylene-inducing xylanase (EIX) & Several plants & [261-264] \\
\hline
\end{tabular}


Table 1. Cont.

\begin{tabular}{cccc}
\hline Origin & Elicitor Molecule & Effects Shown in & References \\
\hline Insects & Fatty acid amides in saliva & Several plants & {$[195]$} \\
\hline & Glucose oxidase in oral secretion & Several plants & {$[194]$} \\
\cline { 2 - 4 } & B-glucosidase in oral secretion & Several plants & {$[194]$} \\
\cline { 2 - 4 } & Inceptin in oral secretion & Several plants & {$[194]$} \\
\cline { 2 - 4 } & Volicitin in oral secretion & Several plants & {$[194]$} \\
\hline Mp10 from aphids & Several plants & {$[194]$} \\
\hline Systemin & S. peruvianum & {$[265]$} \\
\hline PIP1 & Arabidopsis & {$[266]$} \\
\hline Pep1-Pep6 & Arabidopsis & {$[267,268]$} \\
\hline \multirow{4}{*}{ Rhemical } & Arabidopsis & {$[269,270]$} \\
\cline { 2 - 4 } & Oligogalacturonides & Arabidopsis & {$[271]$} \\
\cline { 2 - 4 } & Extracellular ATP & Arabidopsis & {$[272]$} \\
\cline { 2 - 4 } & DL- $\beta$-aminobutyric acid (BABA) & Several plants & {$[242]$} \\
\hline
\end{tabular}

\section{Receptor Molecules: Perception and Activation}

To date, only a few receptors that interact with elicitor molecules have been identified. The perception of elicitors involves surface-based receptors or intracellular receptors that will detect the pathogenic patterns. In most cases, the surface-based receptors are the primary detectors of pathogen-derived elicitors [28]. Receptor-like proteins (RLPs), receptor-like kinases (RLKs), and extracellular binding proteins constitute surface level multicomponent recognition complexes [273]. When specific receptor molecules in plants receive chemical signals released due to injury or pathogen invasion at any part of the plants, the receptor molecules are activated and they transduce the signaling cascade in plants, resulting in the activation of defense responses [192]. Table 2 provides a list of receptor molecules that have been reported thus far.

\subsection{Fungal Receptor Molecules-Examples and Mechanism of Action}

Chitin elicitor binding protein (CEBiP) is one of the receptor molecules involved in fungal chitin binding. This RLP is a LysM domain-containing protein and is essential in rice chitin signaling, which has been proven through studies that used rice cells with CEBiP-RNAi [34]. CEBiP is a chitin-specific receptor molecule, and its response and activity is not affected when other elicitor molecules such as LPS and peptidoglycan are present in the absence of chitin. CEBiP does not have an obvious intracellular domain and needs a partner such as an RLK to translate the perceived chitin signal into intracellular events $[37,274]$. A study proves that chitin elicitor receptor kinase (CERK, an RLK) and CEBiP form a receptor complex where CEBiP detects chitin elicitor molecules that are released in the plant, while OsCERK triggers the defense response by phosphorylating the proteins involved [275]. CEBiP does not have intracellular domains such as CERK and is present on rice cell membranes when the cell is infected by synthetic or pathogen-derived chitin and consequently causes the induction of defense response $[190,276]$. CERK is not only involved in rice immune systems but is also critical for chitin signaling in A. thaliana [36]. CERK1 along with AtLYK5 plays an important role in fungal chitin perception in $A$. thaliana, while OsCERK and OsCEBiP play a similar role in rice [127]. Insertional mutations in CERK block the induction of all chitin-responsive genes, resulting in greater susceptibility to the pathogens [37].

OsCERK and OsCEBiP have important roles in rice for membrane signaling and ligand binding. Both OsCERK and OsCEBiP are known as receptor complexes that form in plants. The formation of this complex is triggered by biologically active chitin oligosaccharides [275] with N-acetyl groups on both sides, which makes the LysM motifs bind to chitin fragments of OsCEBiP [277]. Usually 
for kinases, phosphorylation is required to trigger the activation of catalytic domains that enable the autophosphorylation of intracellular domains [278,279]. However, to date, OsCERK has not been reported to produce dimers [280], although the chitin binding activity of OsCEBiP results in dimerization. The ability of specific mutants to bind chitin fragments does not correlate with dimerization [127]. In the "sandwich-like" model reported by Squeglia et al. (2017), chitin induced the dimerization of OsCEBiP, resulting in OsCERK being closer for the autophosphorylation of receptor kinase to take place. Acetyl moieties of chitin mediate the cross-link operation that dimerizes OsCEBiP molecules [278].

LYP4 and LYP6 are CEBiP-like proteins that are equally reactive to peptidoglycan and chitin [166]. The reactivity of these two proteins toward chitin elicitor is low when the expression of the proteins are low, but there is no clear explanation on the relationship between LYP4/6 and CEBiP or OsCERK [274]. Researchers have reported that the level of $\mathrm{H}_{2} \mathrm{O}_{2}$ generated by CEBiP mutant, cebip, is lower than that observed in non-transformed rice cells. There is also no obvious change in the level of $\mathrm{H}_{2} \mathrm{O}_{2}$ when cebip is treated with peptidoglycan and LPS. A study showed that there is almost no change in the CEBiP expression, $\mathrm{H}_{2} \mathrm{O}_{2}$ generation, and reaction to the chitin elicitor detected in the cebip-cultured cells, which indicates that the chitin elicitor response relies on CEBiP [274,281]. Results from the affinity labeling bespeaks that CEBiP is important in binding to the chitin elicitor in cultured cells and leaves. Studies show that cebip-cultured cells react the same way as wild-type cells in response to peptidoglycan and LPS. As LYP4 and LYP6 engage in the identification of both peptidoglycan and the chitin elicitor, it is not as specific as CEBiP [166].

Although CEBiP is an important chitin elicitor binding protein involved in signaling and the perception of chitin elicitors, any changes to the gene itself do not result in significant change to immunity against rice blast fungus. This indicates that the recognition of chitin-derived oligosaccharides between rice and M. oryzae is limited. This might be due to the competition between LysM Protein 1 (Slp1) that is secreted by M. oryzae and CEBiP in binding to chitin oligosaccharides to repress the chitin elicitor that induces the defense response [282]. Chitin fragments have been identified to activate several defense responses.

In addition, another study found that ethylene-inducing xylanase (EIX), a fungal protein, initiates ethylene biosynthesis, HR, and PR proteins expression in a variety of plants [261-264]. EIX mutants without enzymatic activity have retained the ability to elicit HR, indicating that HR elicitation does not depend on xylanase activity [283-285]. Tomato and tobacco have been used as responding cultivars, where it has been reported that EIX binds specifically to the plasma membrane of both cultivars [286]. There are two members in LeEix locus in tomato that have been characterized: LeEix1 and LeEix2. An experiment was conducted to show the potential of LeEix1 and LeEix2 to bind EIX where both can re-establish the binding to the EIX elicitor, even though only LeEix2 shows positive results in transmitting the signals that are needed to activate HR [145]. There are direct interactions between LeEix2 and EIX elicitor where other plant proteins are not needed in the binding of these two proteins. Transgenic plants treated with LeEix2 bind to the EIX elicitor, and LeEix2 expressed in the COS-7 cells indicates its function as a receptor to the EIX elicitor [145]. LeEix1 is unable to transmit the signal needed to initiate HR, as there is a difference in its cytoplasmic domain compared to LeEix2. The interaction between the EIX elicitor and LeEix2 initiates receptor-mediated endocytosis [145].

In a separate study, two LRR-RLPs that respond to fungal EIX, S1Eix1 and S1Eix2, were found in tomato. EIX acts freely as an elicitor of defense response in tomato and tobacco without depending on endoxylanase activity $[145,284]$. S1Eix 1 and S1Eix2 have a different role, even though both bind to EIX and have $81.4 \%$ similarity. A study proposed that S1Eix1 obstructs the signal for plant defense and plant cell death when it interacts with EIX, since S1Eix1 receptors are deprived of signaling from EIX. S1Eix2 attributes toward conveying signals to actuate the plant immunity $[145,287]$. 


\subsection{Bacterial Receptor Molecules-Examples and Mechanism of Action}

Several studies have identified bacterial receptor molecules that recognize bacterial conserved PAMPs. To begin with, LysM was first recognized in bacteriophages and bacterial proteins. Now, this motif is found to mediate the binding of GlcNAc-containing molecules in addition to being found in peptidoglycan binding proteins [168]. CERK1 is important for peptidoglycan recognition in A. thaliana and rice $[288,289]$. However, some bacterial effectors have been reported to restrict CERK1-mediated signaling [290,291].

In addition, there are other resistance genes that encode receptor molecules involved in plant defensive mechanisms that contribute toward plant resistant phenotypes toward bacteria. These genes include RPS2, [292,293], Pto [294], Xa21 [295], and Cf9 [296] (Table 2). RPS2, Pto, and Cf9 provide narrow-spectrum resistance, while Xa21 provides multi-spectrum resistance to Xanthomonas oryzae pv. oryzae. Xa21 is a kinase that contains non-arginine-aspartate (non-RD) motif and LRR in the extracellular domain [297], which provides the ability to identify LPS [298,299].

Furthermore, the involvement of FLS2 in the identification of flagellin is proven by ectopic expression, where the relationship between flagellin and the expression level of FLS2 results in the activation of the defense system [183]. The C-terminal region of the FLS2 consists of putative protein kinase catalytic domains [300]. The binding of flagellin caused the activation of kinase, which led to the phosphorylation of the target. The Xa21 in rice has a similar gene structure to FLS2 [295], while $C f-2.1$ and $C f-2.2$ (tomato resistance genes) [301] and TOLL like receptors (TIR) are similar to the extracellular domain of FLS2 [302]. Studies show that when plants are treated with flg22, MAMP-mediated immunity is triggered, and plants are protected against pathogens. As the stomata is the common entry for bacteria, stomatal closure occurs upon flagellin perception in plants [303]. The absence of FLS2 in plants makes it more vulnerable to infection, as FLS2 plays a role in early infection where it prevents bacterial entry before it gets into the apoplast [31]. In addition, flg22 also triggers delayed nodule organogenesis in the formation of early symbiosis between Lotus japonicus and Sinorhizobium meliloti [20]. The MAMP trigger immunity (MTI)-suppressing factors might have been secreted into the plants, as there is no consequence of flg22 detected once symbionts are formed [20,304]. However, the proteins that are involved in the identification of different pathogen signal molecules are highly conserved, which shows that similar mechanisms play a role in the interaction and the activation of the defense response against a diverse array of pathogens.

\subsection{Insects Receptor Molecules-Examples and Mechanism of Action}

Insect feeding leads to the rapid accumulation of protease inhibitors throughout the plant, even in undamaged areas far from the initial feeding site [92,305]. Plants recognize insect elicitors that initiate defense response through the activation of kinases and phytohormone networks [104,190,191,306-308]. JA, SA, and ET are the main players in chewing and phloem feeding insect herbivory [305,309]. There are several DAMPs and HAMPs peptides that are available post-processing during insect herbivory [310,311]. A study reported that insects produced prosystemin that lacked $\mathrm{N}$-terminal leader sequence, indicating a passive systemin release [312]. The systemin cell surface receptor from tomato is an LRR receptor kinase, and the binding of systemin to its receptor initiates an intracellular signaling process that results in the activation of JA biosynthesis and accumulation [313]. In target tissues, JA activates the expression of genes that encode protease inhibitors. Since the initial discovery of systemin, many systemin-like signaling peptides have been identified in tomato that have a role to play in pests and pathogens defense [314]. AtPep1-AtPep8 and ZmPep1 are two well-characterized DAMPs in A. thaliana and maize, respectively [311]. Unlike prosystemin, Pep epitopes are in the C-terminus of PROPEP, and these epitopes recognize class XI LRR-RLKs PEPR1/PEPR2 in A. thaliana. The Pep-PERR complex activates broad-spectrum resistance against pathogens, nematodes, and insects [22,315-318]. In addition, the lack of an N-terminal on PROPEP implies that this protein is released through membrane damage [319]. Since PEPR is required for DAMPs' response, the PROPEP most probably has to go through processing to generate active Pep and the activation of defense [316]. Interestingly, 
Peps have been reported to exhibit family-level diversification, as observed in angiosperms that result in recognition specificities [315,320].

Table 2. List of identified receptor molecules in plants against bacteria, fungi, and insects.

\begin{tabular}{|c|c|c|c|}
\hline Gene & Plant & Pathogen & References \\
\hline FLAGELLIN SENSITIVE2 (FLS2) & Arabidopsis thaliana & Bacteria & [183] \\
\hline Xanthomonas oryzae resistance 21 and 26 (Xa21 and Xa26) & Oryza sativa & Bacteria & {$[295,321]$} \\
\hline Ceramide kinase (CERK) & $\begin{array}{l}\text { Arabidopsis thaliana, } \\
\text { Oryza sativa }\end{array}$ & Bacteria and Fungi & [275] \\
\hline Chitin elicitor binding protein (CEBiP) & Arabidopsis thaliana & Fungi & [34] \\
\hline EF-Tu Receptor (EFR) & Arabidopsis thaliana & Bacteria & {$[30]$} \\
\hline $\begin{array}{l}\text { Hypernodulation aberrant } \\
\text { root formation (HAR1) }\end{array}$ & Lotus japonicas & Bacteria & [322] \\
\hline Brassinosteroid LRR receptor kinase (CURL3) & Solanum esculentum & & [265] \\
\hline Ribosomal protein S2 (RPS2) & Arabidopsis thaliana & Bacteria & {$[292,293]$} \\
\hline Resistance to P. syringae (Pto) & Solanum lycopersicum & Bacteria & [294] \\
\hline Cladosporium fulvum resistance protein 9 (Cfg) & Solanum lycopersicum & Fungi & {$[323]$} \\
\hline Systemin Receptor (SYR1) & Solanum lycopersicum & Insect & {$[324]$} \\
\hline Cold Shock Protein Receptor (CORE) & Solanum lycopersicum & Bacteria & [325] \\
\hline $\begin{array}{l}\text { RECEPTOR-LIKE PROTEIN REQUIRED } \\
\text { FOR CSP22 RESPONSIVENES (CSPR) }\end{array}$ & Nicotiana benthamiana & Bacteria & [326] \\
\hline $\begin{array}{l}\text { LIPOOLIGOSACCHARIDE-SPECIFIC REDUCED } \\
\text { ELICITATION (LORE) }\end{array}$ & Arabidopsis thaliana & Bacteria & [327] \\
\hline Receptor like protein 23 (RLP23) & Arabidopsis thaliana & Fungi & [328] \\
\hline $\begin{array}{l}\text { Receptor like protein } 42 \text { (RLP42)/ RESPONSIVENESS TO } \\
\text { BOTRYTIS POLYGALACTURONASES1 (RBPG1) }\end{array}$ & Arabidopsis thaliana & Fungi & [329] \\
\hline Lysin motif protein 1,3,2 (LYM1, LYM3, LYM2) & Arabidopsis thaliana & Bacteria and fungi & {$[288,330]$} \\
\hline PEP receptor 1 and 2 (PEPR1/PEPR2) & Arabidopsis thaliana & Insect & {$[22,267,268,315-318]$} \\
\hline Systemin receptor 160 (SR160) & Solanum peruvianum & Insect & [265] \\
\hline Wall-associated kinase 1 (WAK1) & Arabidopsis thaliana & Bacteria and fungi & [271] \\
\hline S-receptor-like kinase (SRLK) like gene (I-3/I) & $\begin{array}{l}\text { S. pennelli, } \\
\text { S. pimpinellifolium }\end{array}$ & & {$[331,332]$} \\
\hline Receptor like protein 30 (RLP30) & Arabidopsis thaliana & Bacteria and fungi & [333] \\
\hline Receptor like protein 1 (RLP1) & Arabidopsis thaliana & Bacteria & [334] \\
\hline Lysin motif receptor kinase 5 (LYK5) & Arabidopsis thaliana & Fungi & [335] \\
\hline Resistance to Leptosphaeria maculans 23 (RLM/LepR3) & Brassica napus & Fungi & {$[336,337]$} \\
\hline Cladosporium fulvum resistance protein $2 / 4 / 5 / 9(C f-2 / 4 / 5 / 9)$ & Solanaceae & Fungi & {$[114,301,323,338,339]$} \\
\hline Resistance gene homologue Cf-4 (Hcr9-4E) & Solanum hirsutum & Fungi & {$[340,341]$} \\
\hline Does not Respond to Nucleotides1 (DORN1) & Arabidopsis thaliana & Bacteria & [272] \\
\hline Lysin Motif-containing Proteins 4 and 6 (LYP4 and LYP6) & Oryza sativa & Bacteria and Fungi & [166] \\
\hline Secreted LysM Protein1 (Slp1) & Oryza sativa & & [282] \\
\hline Ethylene-inducing xylanase receptor 1 and 2 (LeEix1 and LeEix2) & Solanum lycopersicum & Fungi & [262] \\
\hline $\begin{array}{l}\text { Tomato Ethylene-inducing xylanase receptor } 1 \text { and } 2 \text { (S1Eix1 } \\
\text { and S1Eix2) }\end{array}$ & Solanum lycopersicum & Fungi & {$[262,284,287]$} \\
\hline
\end{tabular}

\subsection{Variations in Elicitors Affect Receptor-Binding Affinity}

Elicitor molecules produced by symbiotic and infectious organisms vary structurally, which enables the host to discriminate between them and provide specialized perception at the plant's cell wall. For instance, the natural occurring differences in pyoverdins produced by WCS358, WCS374, and CHA0 results in the variation of peptide chains produced, which affects the perception of the molecule at the host cell level [214]. NABD, SA, DAPG, pyocyanin, or volatile 2,3-butanediol as determinants of ISR do not show any signs of obvious structural similarities. However, comparing NABD and pure benzylamine indicates that the aromatic amino part of the molecule affects the biological function of these determinants [227]. Similarly, SA and DAPG have an aromatic phenolic 
group that is recognized by specific plant cell receptors. However, lipopeptides contain a less specific mechanism in binding to receptors, as their amphiphilic nature enables LP to insert itself into the lipid bilayer and create channel imbalances in the membrane [342].

In fungi and bacteria, there are two different types of receptor molecules: one that is specific to the taxa of organism and one that is open to both fungi and bacteria. Receptor interaction is largely controlled by the type of elicitor and the ability of the receptor molecule to bind these elicitors. However, there is a difference between microorganisms and insect interaction with regard to receptor molecules, as the protein inhibitors produced by the insects are transmitted directly into the cell through feeding without the need for plant cell surface receptors. Nonetheless, the cascades triggered thereafter are similar with a slight variation in the genes activated between insects and pathogens (Figure 1; Table 2).

\section{Future Prospects and Conclusions}

The interaction between receptor and elicitor molecules provides understanding of the molecular identification, cell biology, and the evolution of the process of defense activation between kingdoms. A thorough study on the function of the plant immune system will support crop development for food safety and security. Given a better understanding of the immune system, researchers will be able to engineer plants with enhanced resistance to disease and pest. Focus is especially on identifying the pathways that activate plant defense in order to improve disease and pest resistance. By understanding the interaction between the elicitor and receptor, researchers can enhance the existing defense system in plants to 'fight' against the invading organism. Here, we list some of the possible applications for the information obtained.

(1) Engineering of crops with disease and pest resistance: Genetic engineering and plant breeding may utilize specific quantitative trait loci (QTLs) or loci with key resistance genes to generate or select for new varieties. These lines may also act as donors in diseases and pest resistance breeding.

(2) Elicitor molecules as triggers of defense: Elicitors from non-virulent strains or attenuated virulent strains may be utilized to trigger the immune response of plants and activate defense signaling that involves SA, ethylene, and JA-dependent/ independent pathways.

(3) Identifying simulating signaling molecules: Inducers such as acibenzolar-S-methyl (ASM) or benzothiadiazole (BTH) are able to activate SAR [105]. Therefore, the identification of various other molecules with similar tendency is encouraged.

(4) Elicitors from beneficial rhizobacteria: The identification of rhizobacterial species with the tendency to secrete chemical components that activate defenses such as LPS, flagellins, siderophores, and SA will be beneficial as biocontrols and plant growth regulators.

(5) Elicitors from beneficial fungi and yeast: Requires the identification of more fungal and yeast strains that are able to generate antimicrobial properties as well as function to induce ISR.

(6) Still searching for receptors: To date, the molecular level activation of defense in response to PAMPs, DAMPs, HAMPs, and MAMPs has not been extensively studied and reported [343]. While the interaction with PAMPs and MAMPs results in activated defenses, there has to be some distinction at the molecular level, as the plant shelters non-pathogenic/beneficial microbes (MAMPs) in the interaction versus antagonistic reaction against pathogens (PAMPs). In addition, plant immunity triggered by MAMPs is based on priming with no reprogramming and fitness cost, while PAMPs results in the direct activation of the arsenal. To date, more plasma membrane receptor molecules have been identified for PAMPs, while MAMP-related receptors have not been reported. In theory, MAMPs would also require some form of binding site for the activation of the defense response [34,145,318,344-346]. The same is true of DAMPs and HAMPs, where little is known on receptors and the receptor-elicitor interactions.

Furthermore, a more extensive dissection of the interaction between elicitor receptor molecules is required to (1) differentiate the responses in a cell surface level versus cytoplasmic receptor system, (2) identify the differences in response to fungi, bacteria, nematode, insects, and other biotic components 
in a elicitor-receptor complex, (3) discriminate between the specific versus nonspecific response of receptors to elicitor or elicitor-like molecules, (4) elucidate if there is a difference between the defense response mounted and the key players in systems with specific versus nonspecific receptors, (5) identify and differentiate at the molecular level the function of PAMP, MAMP, DAMP, and HAMP receptors, and finally (6) critically evaluate the difference between SAR and ISR at the molecular level with specific regard to elicitor-receptor pairings. Through a systematic dissection of the above, we hope that we are able to further understand the complexities involved in the role played by the receptor-elicitor complex in mounting the defense response in plants.

Author Contributions: K.N. worked on the conceptualization of the review. The first draft of this manuscript was written by N.A.A.M. and revised by K.N. The following revisions were made by K.N., I.S.K., and N.A.A.M. All authors have read and agreed to the published version of the manuscript.

Funding: The authors would like to thank Universiti Kebangsaan Malaysia for the facilities and fund (DCP-2017/004/1) and special thanks to the Ministry of Science, Technology and Innovation for the grant provided (Esciencefund 02-01-02-SF1232) and Ministry of Education for FRGS/1/2019/STG03/UKM/01/2.

Conflicts of Interest: The authors declare no conflict of interest.

\section{References}

1. Zipfel, C. Plant pattern-recognition receptors. Trends Immunol. 2014, 35, 345-351. [CrossRef]

2. Chiang, Y.-H.; Coaker, G. Effector triggered immunity: NLR immune perception and downstream defense responses. Arab. Book 2015, 2015, e0183. [CrossRef]

3. Schulze-Lefert, P.; Panstruga, R. A molecular evolutionary concept connecting nonhost resistance, pathogen host range, and pathogen speciation. Trends Plant Sci. 2011, 16, 117-125. [CrossRef] [PubMed]

4. Bonardi, V.; Dangl, J.L. How complex are intracellular immune receptor signaling complexes? Front. Plant Sci. 2012, 3, 237. [CrossRef] [PubMed]

5. Lapin, D.; Van den Ackerveken, G. Susceptibility to plant disease: More than a failure of host immunity. Trends Plant Sci. 2013, 18, 546-554. [CrossRef]

6. Muthamilarasan, M.; Prasad, M. Plant innate immunity: An updated insight into defense mechanism. J. Biosci. 2013, 38, 433-449. [CrossRef]

7. Smale, S.T. Dimer-specific regulatory mechanisms within the NF- $\kappa B$ family of transcription factors. Immunol. Rev. 2012, 246, 193-204. [CrossRef]

8. Pritchard, L.; Birch, P. A systems biology perspective on plant-microbe interactions: Biochemical and structural targets of pathogen effectors. Plant Sci. 2011, 180, 584-603. [CrossRef]

9. Boyd, I.; Freer-Smith, P.; Gilligan, C.; Godfray, H. The consequence of tree pests and diseases for ecosystem services. Science 2013, 342, 1235773. [CrossRef]

10. Kushalappa, A.C.; Yogendra, K.N.; Karre, S. Plant innate immune response: Qualitative and quantitative resistance. Crit. Rev. Plant Sci. 2016, 35, 38-55. [CrossRef]

11. Stael, S.; Kmiecik, P.; Willems, P.; Van Der Kelen, K.; Coll, N.S.; Teige, M.; Van Breusegem, F. Plant innate immunity-sunny side up? Trends Plant Sci. 2015, 20, 3-11. [CrossRef] [PubMed]

12. Chassot, C.; Nawrath, C.; Métraux, J.P. Cuticular defects lead to full immunity to a major plant pathogen. Plant J. 2007, 49, 972-980. [CrossRef] [PubMed]

13. Hammond-Kosack, K. Responses to plant pathogens. In Biochemistry and Molecular Biology of Plants; John Wiley \& Sons Inc.: Rockville, MD, USA, 2000; pp. 1102-1109.

14. Nadarajah, K.; Kassim, N. Effect of signal molecules and hormones on the expression of protein kinase gene OrMKK1 in rice. J. Plant Sci. 2009, 4, 32-42. [CrossRef]

15. Spoel, S.H.; Dong, X. How do plants achieve immunity? Defence without specialized immune cells. Nat. Rev. Immunol. 2012, 12, 89-100. [CrossRef]

16. Ökmen, B.; Doehlemann, G. Inside plant: Biotrophic strategies to modulate host immunity and metabolism. Curr. Opin. Plant Biol. 2014, 20, 19-25. [CrossRef]

17. Koeck, M.; Hardham, A.R.; Dodds, P.N. The role of effectors of biotrophic and hemibiotrophic fungi in infection. Cell. Microbiol. 2011, 13, 1849-1857. [CrossRef] 
18. Lai, Z.; Mengiste, T. Genetic and cellular mechanisms regulating plant responses to necrotrophic pathogens. Curr. Opin. Plant Biol. 2013, 16, 505-512. [CrossRef]

19. Vleeshouwers, V.G.; Oliver, R.P. Effectors as tools in disease resistance breeding against biotrophic, hemibiotrophic, and necrotrophic plant pathogens. Mol. Plant Microbe Interact. 2014, 27, 196-206. [CrossRef]

20. Lopez-Gomez, M.; Sandal, N.; Stougaard, J.; Boller, T. Interplay of flg22-induced defence responses and nodulation in Lotus japonicus. J. Exp. Bot. 2011, 63, 393-401. [CrossRef]

21. Schmidt, S.M.; Panstruga, R. Pathogenomics of fungal plant parasites: What have we learnt about pathogenesis? Curr. Opin. Plant Biol. 2011, 14, 392-399. [CrossRef]

22. Liu, J.; Ding, P.; Sun, T.; Nitta, Y.; Dong, O.; Huang, X.; Yang, W.; Li, X.; Botella, J.R.; Zhang, Y. Heterotrimeric $\mathrm{G}$ proteins serve as a converging point in plant defense signaling activated by multiple receptor-like kinases. Plant Physiol. 2013, 161, 2146-2158. [CrossRef] [PubMed]

23. Fluhr, R. Sentinels of disease. Plant resistance genes. Plant Physiol. 2001, 127, 1367-1374. [CrossRef] [PubMed]

24. Chisholm, S.T.; Coaker, G.; Day, B.; Staskawicz, B.J. Host-microbe interactions: Shaping the evolution of the plant immune response. Cell 2006, 124, 803-814. [CrossRef] [PubMed]

25. Jones, J.D.; Dangl, J.L. The plant immune system. Nature 2006, 444, 323-329. [CrossRef]

26. Boller, T.; He, S.Y. Innate immunity in plants: An arms race between pattern recognition receptors in plants and effectors in microbial pathogens. Science 2009, 324, 742-744. [CrossRef] [PubMed]

27. Dodds, P.N.; Rathjen, J.P. Plant immunity: Towards an integrated view of plant-pathogen interactions. Nat. Rev. Genet. 2010, 11, 539-548. [CrossRef]

28. Sanabria, N.M.; Huang, J.-C.; Dubery, I.A. Self/non-self perception in plants in innate immunity and defense. Self Nonself 2010, 1, 40-54. [CrossRef] [PubMed]

29. Hammond-Kosack, K.E.; Kanyuka, K. Resistance genes ( $R$ genes) in plants. eLS 2007. [CrossRef]

30. Zipfel, C.; Kunze, G.; Chinchilla, D.; Caniard, A.; Jones, J.D.; Boller, T.; Felix, G. Perception of the bacterial PAMP EF-Tu by the receptor EFR restricts Agrobacterium-mediated transformation. Cell 2006, 125, 749-760. [CrossRef]

31. Zipfel, C.; Robatzek, S.; Navarro, L.; Oakeley, E.J.; Jones, J.D.; Felix, G.; Boller, T. Bacterial disease resistance in Arabidopsis through flagellin perception. Nature 2004, 428, 764-767. [CrossRef]

32. Li, X.; Lin, H.; Zhang, W.; Zou, Y.; Zhang, J.; Tang, X.; Zhou, J.-M. Flagellin induces innate immunity in nonhost interactions that is suppressed by Pseudomonas syringae effectors. Proc. Natl. Acad. Sci. USA 2005, 102, 12990-12995. [CrossRef] [PubMed]

33. De Torres, M.; Mansfield, J.W.; Grabov, N.; Brown, I.R.; Ammouneh, H.; Tsiamis, G.; Forsyth, A.; Robatzek, S.; Grant, M.; Boch, J. Pseudomonas syringae effector AvrPtoB suppresses basal defence in Arabidopsis. Plant J. 2006, 47, 368-382. [CrossRef] [PubMed]

34. Kaku, H.; Nishizawa, Y.; Ishii-Minami, N.; Akimoto-Tomiyama, C.; Dohmae, N.; Takio, K.; Minami, E.; Shibuya, N. Plant cells recognize chitin fragments for defense signaling through a plasma membrane receptor. Proc. Natl. Acad. Sci. USA 2006, 103, 11086-11091. [CrossRef] [PubMed]

35. Hann, D.R.; Rathjen, J.P. Early events in the pathogenicity of Pseudomonas syringae on Nicotiana benthamiana. Plant J. 2007, 49, 607-618. [CrossRef] [PubMed]

36. Miya, A.; Albert, P.; Shinya, T.; Desaki, Y.; Ichimura, K.; Shirasu, K.; Narusaka, Y.; Kawakami, N.; Kaku, H.; Shibuya, N. CERK1, a LysM receptor kinase, is essential for chitin elicitor signaling in Arabidopsis. Proc. Natl. Acad. Sci. USA 2007, 104, 19613-19618. [CrossRef]

37. Wan, J.; Zhang, X.-C.; Neece, D.; Ramonell, K.M.; Clough, S.; Kim, S.-y.; Stacey, M.G.; Stacey, G. A LysM receptor-like kinase plays a critical role in chitin signaling and fungal resistance in Arabidopsis. Plant Cell 2008, 20, 471-481. [CrossRef] [PubMed]

38. Conrath, U.; Beckers, G.J.; Langenbach, C.J.; Jaskiewicz, M.R. Priming for enhanced defense. Ann. Rev. Phytopathol. 2015, 53, 97-119. [CrossRef]

39. Bigeard, J.; Colcombet, J.; Hirt, H. Signaling mechanisms in pattern-triggered immunity (PTI). Mol. Plant 2015, 8, 521-539. [CrossRef]

40. Trapet, P.; Kulik, A.; Lamotte, O.; Jeandroz, S.; Bourque, S.; Nicolas-Francès, V.; Rosnoblet, C.; Besson-Bard, A.; Wendehenne, D. NO signaling in plant immunity: A tale of messengers. Phytochemistry 2015, 112, 72-79. [CrossRef]

41. Onaga, G.; Wydra, K. Advances in plant tolerance to abiotic stresses. Plant Genom. 2016, 229-272. [CrossRef] 
42. Saijo, Y.; Loo, E.P.i.; Yasuda, S. Pattern recognition receptors and signaling in plant-microbe interactions. Plant J. 2018, 93, 592-613. [CrossRef]

43. Rodriguez, P.A.; Bos, J.I. Toward understanding the role of aphid effectors in plant infestation. Mol. Plant Microbe Interact. 2013, 26, 25-30. [CrossRef]

44. Beck, M.; Zhou, J.; Faulkner, C.; MacLean, D.; Robatzek, S. Spatio-temporal cellular dynamics of the Arabidopsis flagellin receptor reveal activation status-dependent endosomal sorting. Plant Cell 2012, 24, 4205-4219. [CrossRef]

45. Monaghan, J.; Zipfel, C. Plant pattern recognition receptor complexes at the plasma membrane. Curr. Opin. Plant Biol. 2012, 15, 349-357. [CrossRef] [PubMed]

46. Czernic, P.; Visser, B.; Sun, W.; Savouré, A.; Deslandes, L.; Marco, Y.; Van Montagu, M.; Verbruggen, N. Characterization of an Arabidopsis thaliana receptor-like protein kinase gene activated by oxidative stress and pathogen attack. Plant J. 1999, 18, 321-327. [CrossRef] [PubMed]

47. Pastuglia, M.; Roby, D.; Dumas, C.; Cock, J.M. Rapid induction by wounding and bacterial infection of an S gene family receptor-like kinase gene in Brassica oleracea. Plant Cell 1997, 9, 49-60. [PubMed]

48. Montesano, M.; Kõiv, V.; Mäe, A.; Palva, E.T. Novel receptor-like protein kinases induced by Erwinia carotovora and short oligogalacturonides in potato. Mol. Plant Pathol. 2001, 2, 339-346. [CrossRef] [PubMed]

49. Shiu, S.-H.; Bleecker, A.B. Plant receptor-like kinase gene family: Diversity, function, and signaling. Sci. Stke 2001, 2001, re22. [CrossRef] [PubMed]

50. Creelman, R.A.; Tierney, M.L.; Mullet, J.E. Jasmonic acid/methyl jasmonate accumulate in wounded soybean hypocotyls and modulate wound gene expression. Proc. Natl. Acad. Sci. USA 1992, 89, 4938-4941. [CrossRef] [PubMed]

51. Creelman, R.A.; Mullet, J.E. Jasmonic acid distribution and action in plants: Regulation during development and response to biotic and abiotic stress. Proc. Natl. Acad. Sci. USA 1995, 92, 4114-4119. [CrossRef]

52. Penninckx, I.A.; Thomma, B.P.; Buchala, A.; Métraux, J.-P.; Broekaert, W.F. Concomitant activation of jasmonate and ethylene response pathways is required for induction of a plant defensin gene in Arabidopsis. Plant Cell 1998, 10, 2103-2113. [CrossRef] [PubMed]

53. Katagiri, F.; Tsuda, K. Understanding the plant immune system. Mol. Plant Microbe Interact. 2010, 23, 1531-1536. [CrossRef] [PubMed]

54. Yuan, B.; Zhai, C.; Wang, W.; Zeng, X.; Xu, X.; Hu, H.; Lin, F.; Wang, L.; Pan, Q. The Pik-p resistance to Magnaporthe oryzae in rice is mediated by a pair of closely linked CC-NBS-LRR genes. Theor. Appl. Genet. 2011, 122, 1017-1028. [CrossRef] [PubMed]

55. Zhang, Y.; Yang, X.; Liu, Q.; Qiu, D.; Zhang, Y.; Zeng, H.; Yuan, J.; Mao, J. Purification of novel protein elicitor from Botrytis cinerea that induces disease resistance and drought tolerance in plants. Microbiol. Res. 2010, 165, 142-151. [CrossRef]

56. De Bruyne, L.; Höfte, M.; De Vleesschauwer, D. Connecting growth and defense: The emerging roles of brassinosteroids and gibberellins in plant innate immunity. Mol. Plant 2014, 7, 943-959. [CrossRef]

57. Villena, J.; Kitazawa, H.; Van Wees, S.C.; Pieterse, C.M.; Takahashi, H. Receptors and signaling pathways for recognition of bacteria in livestock and crops: Prospects for beneficial microbes in healthy growth strategies. Front. Immunol. 2018, 9, 2223. [CrossRef]

58. Coll, N.; Epple, P.; Dangl, J. Programmed cell death in the plant immune system. Cell Death Differ. 2011, 18, 1247-1256. [CrossRef]

59. Nadarajah, K. The signaling pathway involved in plant-pathogen interaction in Arabidopsis thaliana. Pak. J. Biol. Sci. 2001, 4, 508-510.

60. Robert-Seilaniantz, A.; Grant, M.; Jones, J.D. Hormone crosstalk in plant disease and defense: More than just jasmonate-salicylate antagonism. Ann. Rev. Phytopathol. 2011, 49, 317-343. [CrossRef]

61. Cook, D.E.; Mesarich, C.H.; Thomma, B.P. Understanding plant immunity as a surveillance system to detect invasion. Ann. Rev. Phytopathol. 2015, 53, 541-563. [CrossRef]

62. Attaran, E.; Zeier, T.E.; Griebel, T.; Zeier, J. Methyl salicylate production and jasmonate signaling are not essential for systemic acquired resistance in Arabidopsis. Plant Cell 2009, 21, 954-971. [CrossRef]

63. Shulaev, V.; Silverman, P.; Raskin, I. Airborne signalling by methyl salicylate in plant pathogen resistance. Nature 1997, 385, 718-721. [CrossRef]

64. Ádám, A.L.; Nagy, Z.Á.; Kátay, G.; Mergenthaler, E.; Viczián, O. Signals of systemic immunity in plants: Progress and open questions. Int. J. Mol. Sci. 2018, 19, 1146. [CrossRef] 
65. Fu, Z.Q.; Yan, S.; Saleh, A.; Wang, W.; Ruble, J.; Oka, N.; Mohan, R.; Spoel, S.H.; Tada, Y.; Zheng, N. NPR3 and NPR4 are receptors for the immune signal salicylic acid in plants. Nature 2012, 486, 228-232. [CrossRef]

66. Luna, E.; Bruce, T.J.; Roberts, M.R.; Flors, V.; Ton, J. Next-generation systemic acquired resistance. Plant Physiol. 2012, 158, 844-853. [CrossRef]

67. Katsir, L.; Chung, H.S.; Koo, A.J.; Howe, G.A. Jasmonate signaling: A conserved mechanism of hormone sensing. Curr. Opin. Plant Biol. 2008, 11, 428-435. [CrossRef]

68. Nadarajah, K.; Sidek, H.M. The green MAPKS. Asian J. Plant Sci. 2010, 9, 1-10. [CrossRef]

69. Mishina, T.E.; Zeier, J. Pathogen-associated molecular pattern recognition rather than development of tissue necrosis contributes to bacterial induction of systemic acquired resistance in Arabidopsis. Plant J. 2007, 50, 500-513. [CrossRef]

70. Nadarajah, K.; Kasim, N.M.; Fui, V.V. Function of Mitogen-Activated Protein Kinase Gene in Biotic Stress. Asian J. Plant Sci. 2009, 8, 191-198. [CrossRef]

71. Lo Presti, L.; Lanver, D.; Schweizer, G.; Tanaka, S.; Liang, L.; Tollot, M.; Zuccaro, A.; Reissmann, S.; Kahmann, R. Fungal effectors and plant susceptibility. Ann. Rev. Plant Biol. 2015, 66, 513-545. [CrossRef]

72. Glazebrook, J. Contrasting mechanisms of defense against biotrophic and necrotrophic pathogens. Ann. Rev. Phytopathol. 2005, 43, 205-227. [CrossRef]

73. Bari, R.; Jones, J.D. Role of plant hormones in plant defence responses. Plant Mol. Biol. 2009, 69, 473-488. [CrossRef]

74. Mishra, A.K.; Sharma, K.; Misra, R.S. Elicitor recognition, signal transduction and induced resistance in plants. J. Plant Interact. 2012, 7, 95-120. [CrossRef]

75. Beneduzi, A.; Ambrosini, A.; Passaglia, L.M. Plant growth-promoting rhizobacteria (PGPR): Their potential as antagonists and biocontrol agents. Genet. Mol. Biol. 2012, 35, 1044-1051. [CrossRef]

76. Caplan, J.; Padmanabhan, M.; Dinesh-Kumar, S.P. Plant NB-LRR immune receptors: From recognition to transcriptional reprogramming. Cell Host Microbe 2008, 3, 126-135. [CrossRef]

77. van der Hoorn, R.A.; Kamoun, S. From guard to decoy: A new model for perception of plant pathogen effectors. Plant Cell 2008, 20, 2009-2017. [CrossRef]

78. De Jonge, R.; Van Esse, H.P.; Kombrink, A.; Shinya, T.; Desaki, Y.; Bours, R.; Van Der Krol, S.; Shibuya, N.; Joosten, M.H.; Thomma, B.P. Conserved fungal LysM effector Ecp6 prevents chitin-triggered immunity in plants. Science 2010, 329, 953-955. [CrossRef]

79. Saintenac, C.; Zhang, W.; Salcedo, A.; Rouse, M.N.; Trick, H.N.; Akhunov, E.; Dubcovsky, J. Identification of wheat gene Sr35 that confers resistance to Ug99 stem rust race group. Science 2013, 341, 783-786. [CrossRef]

80. Wu, C.-H.; Krasileva, K.V.; Banfield, M.J.; Terauchi, R.; Kamoun, S. The "sensor domains" of plant NLR proteins: More than decoys? Front. Plant Sci. 2015, 6, 134. [CrossRef]

81. Cook, K.; Netthisinghe, A.; Gilfillen, R. Detection of pathogens, indicators, and antibiotic resistance genes after land application of poultry litter. J. Environ. Qual. 2014, 43, 1546-1558. [CrossRef]

82. Pritchard, L.; Birch, P. The zigzag model of plant-microbe interactions: Is it time to move on? Mol. Plant Pathol. 2014, 15, 865-870. [CrossRef] [PubMed]

83. Andolfo, G.; Iovieno, P.; Frusciante, L.; Ercolano, M.R. Genome-editing technologies for enhancing plant disease resistance. Front. Plant Sci. 2016, 7, 1813. [CrossRef] [PubMed]

84. Nadarajah, K.; Ali, H.Z.; Muni, N.M. The host pathogen interactions observed between 'Fusarium' sp. F2 and rice. Plant Omics 2015, 8, 572-580.

85. Nürnberger, T.; Scheel, D. Signal transmission in the plant immune response. Trends Plant Sci. 2001, 6, 372-379. [CrossRef]

86. Hammond-Kosack, K.E.; Jones, J. Resistance gene-dependent plant defense responses. Plant Cell 1996, 8 , 1773-1791.

87. Pennell, R.L.; Lamb, C. Programmed cell death in plants. Plant Cell 1997, 9, 1157-1168. [CrossRef] [PubMed]

88. Kumar, J.; Hückelhoven, R.; Beckhove, U.; Nagarajan, S.; Kogel, K.-H. A compromised Mlo pathway affects the response of barley to the necrotrophic fungus Bipolaris sorokiniana (teleomorph: Cochliobolus sativus) and its toxins. Phytopathology 2001, 91, 127-133. [CrossRef]

89. Delledonne, M.; Zeier, J.; Marocco, A.; Lamb, C. Signal interactions between nitric oxide and reactive oxygen intermediates in the plant hypersensitive disease resistance response. Proc. Natl. Acad. Sci. USA 2001, 98, 13454-13459. [CrossRef] 
90. Baker, C.J.; O’Neill, N.R.; Keepler, L.D.; Orlandi, E.W. Oxygen metabolism in plant/bacteria interactions: Characterization of the oxygen uptake response of plant suspension cells. Physiol. Mol. Plant Pathol. 2002, 59, 29-32. [CrossRef]

91. Peumans, W.J.; Van Damme, E.J. Lectins as plant defense proteins. Plant Physiol. 1995, 9, 347-352. [CrossRef]

92. Schilmiller, A.L.; Howe, G.A. Systemic signaling in the wound response. Curr. Opin. Plant Biol. 2005, 8, 369-377. [CrossRef] [PubMed]

93. Johnson, R.; Narvaez, J.; An, G.; Ryan, C. Expression of proteinase inhibitors I and II in transgenic tobacco plants: Effects on natural defense against Manduca sexta larvae. Proc. Natl. Acad. Sci. USA 1989, 86, 9871-9875. [CrossRef] [PubMed]

94. Hain, R.; Reif, H.J.; Krause, E.; Langebartels, R.; Kindl, H.; Vornam, B.; Wiese, W.; Schmelzer, E.; Schreier, P.H.; Stocker, R.H.; et al. Disease resistance results from foreign phytoalexin expression in a novel plant. Nature 1993, 361, 153-156. [CrossRef] [PubMed]

95. Kombrink, E.; Somssich, I.E. Defence responses of plants to pathogens. Adv. Bot. Res. 1995, 21, 1-34.

96. Schwyzer, R. Structure and function in neuropeptides. Proc. R. Soc. Lond. B Biol. Sci. 1980, 210, 5-20.

97. Albert, M.; Jehle, A.K.; Lipschis, M.; Mueller, K.; Zeng, Y.; Felix, G. Regulation of cell behaviour by plant receptor kinases: Pattern recognition receptors as prototypical models. Eur. J. Cell Biol. 2010, 89, 200-207. [CrossRef]

98. Boller, T. Chemoperception of Microbial Signals in Plant Cells. Ann. Rev. Plant Physiol. Plant Mol. Biol. 1995, 46, 189-214. [CrossRef]

99. D’Ovidio, R.; Mattei, B.; Roberti, S.; Bellincampi, D. Polygalacturonases, polygalacturonase-inhibiting proteins and pectic oligomers in plant-pathogen interactions. Biochim. Biophys. Acta 2004, 1696, 237-244. [CrossRef]

100. Montesano, M.; Brader, G.; Palva, E.T. Pathogen derived elicitors: Searching for receptors in plants. Mol. Plant Pathol. 2003, 4, 73-79. [CrossRef]

101. Hu, G.; deHart, A.K.; Li, Y.; Ustach, C.; Handley, V.; Navarre, R.; Hwang, C.F.; Aegerter, B.J.; Williamson, V.M.; Baker, B. EDS1 in tomato is required for resistance mediated by TIR-class R genes and the receptor-like $\mathrm{R}$ gene Ve. Plant J. 2005, 42, 376-391. [CrossRef]

102. Nürnberger, T. Signal perception in plant pathogen defense. Cell. Mol. Life Sci. CMLS 1999, 55, 167-182. [CrossRef] [PubMed]

103. Côté, F.; Hahn, M.G. Oligosaccharins: Structures and signal transduction. Plant Mol. Biol. 1994, 26, $1379-1411$. [CrossRef] [PubMed]

104. Mishra, B.B.; Tripathi, S.; Tripathi, C. Repellent effect of leaves essential oils from Eucalyptus globulus (Mirtaceae) and Ocimum basilicum (Lamiaceae) against two major stored grain insect pests of Coleopterons. Nat. Sci. 2012, 10, 50-54.

105. Thakur, M.; Sohal, B.S. Role of elicitors in inducing resistance in plants against pathogen infection: A review. ISRN Biochem. 2013, 2013, 762412. [CrossRef]

106. Dalio, R.J.; Magalhaes, D.M.; Rodrigues, C.M.; Arena, G.D.; Oliveira, T.S.; Souza-Neto, R.R.; Picchi, S.C.; Martins, P.M.; Santos, P.J.; Maximo, H.J. PAMPs, PRRs, effectors and R-genes associated with citrus-pathogen interactions. Ann. Bot. 2017, 119, 749-774.

107. Yamaguchi, T.; Yamada, A.; Hong, N.; Ogawa, T.; Ishii, T.; Shibuya, N. Differences in the recognition of glucan elicitor signals between rice and soybean: $\beta$-glucan fragments from the rice blast disease fungus Pyricularia oryzae that elicit phytoalexin biosynthesis in suspension-cultured rice cells. Plant Cell 2000, 12, 817-826.

108. Shibuya, N.; Minami, E. Oligosaccharide signalling for defence responses in plant. Physiol. Mol. Plant Pathol. 2001, 59, 223-233. [CrossRef]

109. Raaymakers, T.M.; Van den Ackerveken, G. Extracellular recognition of oomycetes during biotrophic infection of plants. Front. Plant Sci. 2016, 7, 906. [CrossRef]

110. Farrell, K.; Jahan, M.; Kovinich, N. Distinct mechanisms of biotic and chemical elicitors enable additive elicitation of the anticancer phytoalexin glyceollin I. Molecules 2017, 22, 1261. [CrossRef]

111. Bonas, U.; Lahaye, T. Plant disease resistance triggered by pathogen-derived molecules: Refined models of specific recognition. Curr. Opin. Microbiol. 2002, 5, 44-50. [CrossRef]

112. McConn, M.; Creelman, R.A.; Bell, E.; Mullet, J.E. Jasmonate is essential for insect defense in Arabidopsis. Proc. Natl. Acad. Sci. USA 1997, 94, 5473-5477. [CrossRef] [PubMed]

113. Cohn, J.; Sessa, G.; Martin, G.B. Innate immunity in plants. Curr. Opin. Immunol. 2001, 13, 55-62. [CrossRef] 
114. Luderer, R.; Joosten, M.H. Avirulence proteins of plant pathogens: Determinants of victory and defeat. Mol. Plant Pathol. 2001, 2, 355-364. [CrossRef] [PubMed]

115. Nimchuk, Z.; Rohmer, L.; Chang, J.H.; Dangl, J.L. Knowing the dancer from the dance: R-gene products and their interactions with other proteins from host and pathogen. Curr. Opin. Plant Biol. 2001, 4, 288-294. [CrossRef]

116. Hammond-Kosack, K.E.; Jones, J.D. Plant disease resistance genes. Ann. Rev. Plant Biol. 1997, 48, $575-607$. [CrossRef] [PubMed]

117. Tyler, B.M. Molecular basis of recognition between Phytophthora pathogens and their hosts. Ann. Rev. Phytopathol. 2002, 40, 137-167. [CrossRef]

118. Ebel, J.; Cosio, E.G. Elicitors of plant defence responses. Int. Rev. Cytol. 1994, 148, 1-36.

119. Cullimore, J.V.; Ranjeva, R.; Bono, J.-J. Perception of lipo-chitooligosaccharidic Nod factors in legumes. Trends Plant Sci. 2001, 6, 24-30. [CrossRef]

120. El-Ghaouth, A.; Arul, J.; Grenier, J.; Benhamou, N.; Asselin, A.; Belanger, R. Effect of chitosan on cucumber plants: Suppression of Pythium aphanidermatum and induction of defense reactions. Phytopathology 1994, 84, 313-320. [CrossRef]

121. Copping, L.G.; Duke, S.O. Natural products that have been used commercially as crop protection agents. Pest Manag. Sci. Former. Pestic. Sci. 2007, 63, 524-554. [CrossRef]

122. Kishimoto, K.; Kouzai, Y.; Kaku, H.; Shibuya, N.; Minami, E.; Nishizawa, Y. Perception of the chitin oligosaccharides contributes to disease resistance to blast fungus Magnaporthe oryzae in rice. Plant J. 2010, 64, 343-354. [CrossRef] [PubMed]

123. Kombrink, A.; Sanchez-Vallet, A.; Thomma, B.P. The role of chitin detection in plant-pathogen interactions. Microbes Infect. 2011, 13, 1168-1176. [CrossRef]

124. El Hadrami, A.; Adam, L.R.; El Hadrami, I.; Daayf, F. Chitosan in plant protection. Mar. Drugs 2010, 8, 968-987. [CrossRef]

125. Pusztahelyi, T. Chitin and chitin-related compounds in plant-fungal interactions. Mycology 2018, 9, $189-201$. [CrossRef] [PubMed]

126. Vander, P.; Vårum, K.M.; Domard, A.; El Gueddari, N.E.; Moerschbacher, B.M. Comparison of the ability of partially $\mathrm{N}$-acetylated chitosans and chitooligosaccharides to elicit resistance reactions in wheat leaves. Plant Physiol. 1998, 118, 1353-1359. [CrossRef] [PubMed]

127. Hayafune, M.; Berisio, R.; Marchetti, R.; Silipo, A.; Kayama, M.; Desaki, Y.; Arima, S.; Squeglia, F.; Ruggiero, A.; Tokuyasu, K.; et al. Chitin-induced activation of immune signaling by the rice receptor CEBiP relies on a unique sandwich-type dimerization. Proc. Natl. Acad. Sci. USA 2014, 111, E404-E413. [CrossRef]

128. Ning, W.; Chen, F.; Mao, B.; Li, Q.; Liu, Z.; Guo, Z.; He, Z. N-acetylchitooligosaccharides elicit rice defence responses including hypersensitive response-like cell death, oxidative burst and defence gene expression. Physiol. Mol. Plant Pathol. 2004, 64, 263-271. [CrossRef]

129. Minami, E.; Kuchitsu, K.; He, D.-Y.; Kouchi, H.; Midoh, N.; Ohtsuki, Y.; Shibuya, N. Two novel genes rapidly and transiently activated in suspension-cultured rice cells by treatment with $\mathrm{N}$-acetylchitoheptaose, a biotic elicitor for phytoalexin production. Plant Cell Physiol. 1996, 37, 563-567. [CrossRef]

130. Nishizawa, Y.; Kawakami, A.; Hibi, T.; He, D.-Y.; Shibuya, N.; Minami, E. Regulation of the chitinase gene expression in suspension-cultured rice cells by $\mathrm{N}$-acetylchitooligosaccharides: Differences in the signal transduction pathways leading to the activation of elicitor-responsive genes. Plant Mol. Biol. 1999, 39, 907-914. [CrossRef]

131. Day, R.B.; Okada, M.; Ito, Y.; Tsukada, K.; Zaghouani, H.; Shibuya, N.; Stacey, G. Binding site for chitin oligosaccharides in the soybean plasma membrane. Plant Physiol. 2001, 126, 1162-1173. [CrossRef]

132. Felix, G.; Regenass, M.; Boller, T. Specific perception of subnanomolar concentrations of chitin fragments by tomato cells: Induction of extracellular alkalinization, changes in protein phosphorylation, and establishment of a refractory state. Plant J. 1993, 4, 307-316. [CrossRef]

133. Kuchitsu, K.; Yazaki, Y.; Sakano, K.; Shibuya, N. Transient cytoplasmic pH change and ion fluxes through the plasma memberan in suspension-cultured rice cells triggered by $\mathrm{N}$-acetylchitooligosaccharide elicitor. Plant Cell Physiol. 1997, 38, 1012-1018. [CrossRef]

134. Müller, J.; Staehelin, C.; Xie, Z.-P.; Neuhaus-Url, G.; Boller, T. Nod factors and chitooligomers elicit an increase in cytosolic calcium in aequorin-expressing soybean cells. Plant Physiol. 2000, 124, 733-740. [CrossRef] 
135. Kuchitsu, K.; Kosaka, H.; Shiga, T.; Shibuya, N. EPR evidence for generation of hydroxyl radical triggered byN-acetylchitooligosaccharide elicitor and a protein phosphatase inhibitor in suspension-cultured rice cells. Protoplasma 1995, 188, 138-142. [CrossRef]

136. Tsukada, K.; Ishizaka, M.; Fujisawa, Y.; Iwasaki, Y.; Yamaguchi, T.; Minami, E.; Shibuya, N. Rice receptor for chitin oligosaccharide elicitor does not couple to heterotrimeric G-protein: Elicitor responses of suspension cultured rice cells from Daikoku dwarf (d1) mutants lacking a functional G-protein $\alpha$-subunit. Physiol. Plant. 2002, 116, 373-382. [CrossRef]

137. Pérez-Pérez, M.E.; Lemaire, S.D.; Crespo, J.L. Reactive oxygen species and autophagy in plants and algae. Plant Physiol. 2012, 160, 156-164. [CrossRef] [PubMed]

138. Inui, H.; Yamaguchi, Y.; Hirano, S. Elicitor actions of N-acetylchitooligosaccharides and laminarioligosaccharides for chitinase and L-phenylalanine ammonia-lyase induction in rice suspension culture. Biosci. Biotechnol. Biochem. 1997, 61, 975-978. [CrossRef] [PubMed]

139. Ren, Y.-Y.; West, C.A. Elicitation of diterpene biosynthesis in rice (Oryza sativa L.) by chitin. Plant Physiol. 1992, 99, 1169-1178. [CrossRef]

140. Kuchitsu, K.; Kikuyama, M.; Shibuya, N. N-acetylchitooligosaccharides, biotic elicitor for phytoalexin production, induce transient membrane depolarization in suspension-cultured rice cells. Protoplasma 1993, 174, 79-81. [CrossRef]

141. Yamada, A.; Shibuya, N.; Kodama, O.; Akatsuka, T. Induction of phytoalexin formation in suspension-cultured rice cells by $\mathrm{N}$-acetylchitooligosaccharides. Biosci. Biotechnol. Biochem. 1993, 57, 405-409. [CrossRef]

142. Kombrink, E.; Schmelzer, E. The hypersensitive response and its role in local and systemic disease resistance. Eur. J. Plant Pathol. 2001, 107, 69-78. [CrossRef]

143. Lawrence, C.B.; Singh, N.P.; Qiu, J.; Gardner, R.G.; Tuzun, S. Constitutive hydrolytic enzymes are associated with polygenic resistance of tomato to Alternaria solani and may function as an elicitor release mechanism. Physiol. Mol. Plant Pathol. 2000, 57, 211-220. [CrossRef]

144. Zhang, H.K.; Zhang, X.; Mao, B.Z.; Qun, L.; Zu Hua, H. Alpha-picolinic acid, a fungal toxin and mammal apoptosis-inducing agent, elicits hypersensitive-like response and enhances disease resistance in rice. Cell Res. 2004, 14, 27-33. [CrossRef] [PubMed]

145. Ron, M.; Avni, A. The receptor for the fungal elicitor ethylene-inducing xylanase is a member of a resistance-like gene family in tomato. Plant Cell 2004, 16, 1604-1615. [CrossRef]

146. Umemura, K.; Ogawa, N.; Koga, J.; Iwata, M.; Usami, H. Elicitor activity of cerebroside, a sphingolipid elicitor, in cell suspension cultures of rice. Plant Cell Physiol. 2002, 43, 778-784. [CrossRef]

147. Umemura, K.; Tanino, S.; Nagatsuka, T.; Koga, J.; Iwata, M.; Nagashima, K.; Amemiya, Y. Cerebroside elicitor confers resistance to Fusarium disease in various plant species. Phytopathology 2004, 94, 813-818. [CrossRef]

148. Hahn, M.G. Microbial elicitors and their receptors in plants. Annu Rev Phytopathol. 1996, 34, $387-412$. [CrossRef]

149. Ménard, R.; Alban, S.; de Ruffray, P.; Jamois, F.; Franz, G.; Fritig, B.; Yvin, J.-C.; Kauffmann, S. $\beta-1,3$ glucan sulfate, but not $\beta-1,3$ glucan, induces the salicylic acid signaling pathway in tobacco and Arabidopsis. Plant Cell 2004, 16, 3020-3032. [CrossRef]

150. Henry, E.; Yadeta, K.A.; Coaker, G. Recognition of bacterial plant pathogens: Local, systemic and transgenerational immunity. New Phytol. 2013, 199, 908-915. [CrossRef]

151. Abramovitch, R.B.; Anderson, J.C.; Martin, G.B. Bacterial elicitation and evasion of plant innate immunity. Nat. Rev. Mol. Cell Biol. 2006, 7, 601-611. [CrossRef]

152. Agrios, G.N. Plant Pathology; Academic Press: San Diego, CA, USA, 1997; Volume 4.

153. Segonzac, C.; Zipfel, C. Activation of plant pattern-recognition receptors by bacteria. Curr. Opin. Microbiol. 2011, 14, 54-61. [CrossRef] [PubMed]

154. Wei, Z.-M.; Laby, R.J.; Zumoff, C.H.; Bauer, D.W.; He, S.Y.; Collmer, A.; Beer, S.V. Harpin, elicitor of the hypersensitive response produced by the plant pathogen Erwinia amylovora. Science 1992, 257, 85-88. [CrossRef] [PubMed]

155. Dong, H.; Delaney, T.P.; Bauer, D.W.; Beer, S.V. Harpin induces disease resistance in Arabidopsis through the systemic acquired resistance pathway mediated by salicylic acid and the NIM1 gene. Plant J. 1999, 20, 207-215. [CrossRef] [PubMed]

156. Cui, H.; Xiang, T.; Zhou, J.M. Plant immunity: A lesson from pathogenic bacterial effector proteins. Cell. Microbiol. 2009, 11, 1453-1461. [CrossRef] 
157. Vance, R.E.; Isberg, R.R.; Portnoy, D.A. Patterns of pathogenesis: Discrimination of pathogenic and nonpathogenic microbes by the innate immune system. Cell Host Microbe 2009, 6, 10-21. [CrossRef]

158. Oh, H.-S.; Park, D.H.; Collmer, A. Components of the Pseudomonas syringae type III secretion system can suppress and may elicit plant innate immunity. Mol. Plant Microbe Interact. 2010, 23, 727-739. [CrossRef]

159. Boller, T.; Felix, G. A renaissance of elicitors: Perception of microbe-associated molecular patterns and danger signals by pattern-recognition receptors. Ann. Rev. Plant Biol. 2009, 60, 379-406. [CrossRef]

160. Felix, G.; Boller, T. Molecular Sensing of Bacteria in Plants the highly conserved rna-binding motif rnp-1 of bacterial cold shock proteins is recognized as an elicitor signal in tobacco. J. Biol. Chem. 2003, 278, 6201-6208. [CrossRef]

161. Dworkin, J. The medium is the message: Interspecies and interkingdom signaling by peptidoglycan and related bacterial glycans. Ann. Rev. Microbiol. 2014, 68, 137-154. [CrossRef]

162. Bertsche, U.; Mayer, C.; Götz, F.; Gust, A.A. Peptidoglycan perception-Sensing bacteria by their common envelope structure. Int. J. Med. Microbiol. 2015, 305, 217-223. [CrossRef]

163. Gust, A.A.; Biswas, R.; Lenz, H.D.; Rauhut, T.; Ranf, S.; Kemmerling, B.; Götz, F.; Glawischnig, E.; Lee, J.; Felix, G. Bacteria-derived peptidoglycans constitute pathogen-associated molecular patterns triggering innate immunity in Arabidopsis. J. Biol. Chem. 2007, 282, 32338-32348. [CrossRef]

164. Erbs, G.; Silipo, A.; Aslam, S.; De Castro, C.; Liparoti, V.; Flagiello, A.; Pucci, P.; Lanzetta, R.; Parrilli, M.; Molinaro, A. Peptidoglycan and muropeptides from pathogens Agrobacterium and Xanthomonas elicit plant innate immunity: Structure and activity. Chem. Biol. 2008, 15, 438-448. [CrossRef]

165. Millet, Y.A.; Danna, C.H.; Clay, N.K.; Songnuan, W.; Simon, M.D.; Werck-Reichhart, D.; Ausubel, F.M. Innate immune responses activated in Arabidopsis roots by microbe-associated molecular patterns. Plant Cell 2010, 22, 973-990. [CrossRef] [PubMed]

166. Liu, B.; Li, J.-F.; Ao, Y.; Qu, J.; Li, Z.; Su, J.; Zhang, Y.; Liu, J.; Feng, D.; Qi, K. Lysin motif-containing proteins LYP4 and LYP6 play dual roles in peptidoglycan and chitin perception in rice innate immunity. Plant Cell 2012, 24, 3406-3419. [CrossRef] [PubMed]

167. Wiesel, L.; Newton, A.C.; Elliott, I.; Booty, D.; Gilroy, E.M.; Birch, P.R.; Hein, I. Molecular effects of resistance elicitors from biological origin and their potential for crop protection. Front. Plant Sci. 2014, 5, 655. [CrossRef] [PubMed]

168. Gust, A.A. Peptidoglycan perception in plants. PLoS Pathog. 2015, 11, e1005275. [CrossRef]

169. Desaki, Y.; Miya, A.; Venkatesh, B.; Tsuyumu, S.; Yamane, H.; Kaku, H.; Minami, E.; Shibuya, N. Bacterial lipopolysaccharides induce defense responses associated with programmed cell death in rice cells. Plant Cell Physiol. 2006, 47, 1530-1540. [CrossRef]

170. Meyer, A.; Pühler, A.; Niehaus, K. The lipopolysaccharides of the phytopathogen Xanthomonas campestris pv. campestris induce an oxidative burst reaction in cell cultures of Nicotiana tabacum. Planta 2001, 213, $214-222$. [CrossRef]

171. Gerber, I.B.; Zeidler, D.; Durner, J.; Dubery, I.A. Early perception responses of Nicotiana tabacum cells in response to lipopolysaccharides from Burkholderia cepacia. Planta 2004, 218, 647-657. [CrossRef]

172. Coventry, H.S.; Dubery, I.A. Lipopolysaccharides from Burkholderia cepacia contribute to an enhanced defensive capacity and the induction of pathogenesis-related proteins in Nicotianae tabacum. Physiol. Mol. Plant Pathol. 2001, 58, 149-158. [CrossRef]

173. Silipo, A.; Molinaro, A.; Sturiale, L.; Dow, J.M.; Erbs, G.; Lanzetta, R.; Newman, M.-A.; Parrilli, M. The elicitation of plant innate immunity by lipooligosaccharide of Xanthomonas campestris. J. Biol. Chem. 2005, 280, 33660-33668. [CrossRef] [PubMed]

174. Zeidler, D.; Zähringer, U.; Gerber, I.; Dubery, I.; Hartung, T.; Bors, W.; Hutzler, P.; Durner, J. Innate immunity in Arabidopsis thaliana: Lipopolysaccharides activate nitric oxide synthase (NOS) and induce defense genes. Proc. Natl. Acad. Sci. USA 2004, 101, 15811-15816. [CrossRef] [PubMed]

175. Leeman, M.; Van Pelt, J.; Den Ouden, F.; Heinsbroek, M.; Bakker, P.; Schippers, B. Induction of systemic resistance against Fusarium wilt of radish by lipopolysaccharides of Pseudomonas fluorescens. Phytopathology 1995, 85, 1021-1027. [CrossRef]

176. Van Wees, S.C.; Pieterse, C.M.; Trijssenaar, A.; Van't Westende, Y.A.; Hartog, F.; Van Loon, L.C. Differential induction of systemic resistance in Arabidopsis by biocontrol bacteria. Mol. Plant Microbe Interact. 1997, 10, 716-724. [CrossRef] 
177. Reitz, M.; Rudolph, K.; Schröder, I.; Hoffmann-Hergarten, S.; Hallmann, J.; Sikora, R. Lipopolysaccharides of Rhizobium etli Strain G12 Act in Potato Roots as an Inducing Agent of Systemic Resistance to Infection by the Cyst Nematode Globodera pallida. Appl. Environ. Microbiol. 2000, 66, 3515-3518. [CrossRef]

178. Bedini, E.; De Castro, C.; Erbs, G.; Mangoni, L.; Dow, J.M.; Newman, M.-A.; Parrilli, M.; Unverzagt, C. Structure-dependent modulation of a pathogen response in plants by synthetic O-antigen polysaccharides. J. Am. Chem. Soc. 2005, 127, 2414-2416. [CrossRef]

179. Braun, S.G.; Meyer, A.; Holst, O.; Pühler, A.; Niehaus, K. Characterization of the Xanthomonas campestris pv. campestris lipopolysaccharide substructures essential for elicitation of an oxidative burst in tobacco cells. Mol. Plant Microbe Interact. 2005, 18, 674-681. [CrossRef]

180. Silipo, A.; Erbs, G.; Shinya, T.; Dow, J.M.; Parrilli, M.; Lanzetta, R.; Shibuya, N.; Newman, M.-A.; Molinaro, A. Glyco-conjugates as elicitors or suppressors of plant innate immunity. Glycobiology 2010, 20, 406-419. [CrossRef]

181. Madala, N.E.; Molinaro, A.; Dubery, I.A. Distinct carbohydrate and lipid-based molecular patterns within lipopolysaccharides from Burkholderia cepacia contribute to defense-associated differential gene expression in Arabidopsis thaliana. Innate Immun. 2012, 18, 140-154. [CrossRef]

182. Newman, M.-A.; Sundelin, T.; Nielsen, J.T.; Erbs, G. MAMP (microbe-associated molecular pattern) triggered immunity in plants. Front. Plant Sci. 2013, 4, 139. [CrossRef]

183. Gómez-Gómez, L.; Boller, T. FLS2: An LRR receptor-like kinase involved in the perception of the bacterial elicitor flagellin in Arabidopsis. Mol. Cell 2000, 5, 1003-1011. [CrossRef]

184. Keinath, N.F.; Kierszniowska, S.; Lorek, J.; Bourdais, G.; Kessler, S.A.; Asano, H.; Grossniklaus, U.; Schulze, W.; Robatzek, S.; Panstruga, R. PAMP-induced changes in plasma membrane compartmentalization reveal novel components of plant immunity. J. Biol. Chem. 2010, 285, 39140-39149. [CrossRef] [PubMed]

185. Roux, M.; Schwessinger, B.; Albrecht, C.; Chinchilla, D.; Jones, A.; Holton, N.; Malinovsky, F.G.; Tör, M.; de Vries, S.; Zipfel, C. The Arabidopsis leucine-rich repeat receptor-like kinases BAK1/SERK3 and BKK1/SERK4 are required for innate immunity to hemibiotrophic and biotrophic pathogens. Plant Cell 2011, 23, 2440-2455. [CrossRef] [PubMed]

186. von Heijne, G. The signal peptide. J. Membr. Biol. 1990, 115, 195-201. [CrossRef] [PubMed]

187. Medzhitov, R.; Janeway, C.A., Jr. An ancient system of host defense. Curr. Opin. Immunol. 1998, 10, 12-15. [CrossRef]

188. Erb, M.; Meldau, S.; Howe, G.A. Role of phytohormones in insect-specific plant reactions. Trends Plant Sci. 2012, 17, 250-259. [CrossRef]

189. Fürstenberg-Hägg, J.; Zagrobelny, M.; Bak, S. Plant defense against insect herbivores. Int. J. Mol. Sci. 2013, 14, 10242-10297. [CrossRef]

190. Shinya, T.; Hojo, Y.; Desaki, Y.; Christeller, J.T.; Okada, K.; Shibuya, N.; Galis, I. Modulation of plant defense responses to herbivores by simultaneous recognition of different herbivore-associated elicitors in rice. Sci. Rep. 2016, 6, 32537. [CrossRef]

191. War, A.R.; Taggar, G.K.; Hussain, B.; Taggar, M.S.; Nair, R.M.; Sharma, H.C. Plant defence against herbivory and insect adaptations. AoB Plants 2018, 10, ply037.

192. Mithöfer, A.; Boland, W. Recognition of herbivory-associated molecular patterns. Plant Physiol. 2008, 146, 825-831. [CrossRef]

193. Hogenhout, S.A.; Bos, J.I. Effector proteins that modulate plant-insect interactions. Curr. Opin. Plant Biol. 2011, 14, 422-428. [CrossRef]

194. Wu, J.; Baldwin, I.T. Herbivory-induced signalling in plants: Perception and action. Plant Cell Environ. 2009, 32, 1161-1174. [CrossRef]

195. Alborn, H.; Turlings, T.; Jones, T.H.; Stenhagen, G.; Loughrin, J.; Tumlinson, J. An elicitor of plant volatiles from beet armyworm oral secretion. Science 1997, 276, 945-949. [CrossRef]

196. Schmelz, E.A.; Engelberth, J.; Alborn, H.T.; Tumlinson, J.H.; Teal, P.E. Phytohormone-based activity mapping of insect herbivore-produced elicitors. Proc. Natl. Acad. Sci. USA 2009, 106, 653-657. [CrossRef]

197. Halitschke, R.; Schittko, U.; Pohnert, G.; Boland, W.; Baldwin, I.T. Molecular interactions between the specialist Herbivoremanduca sexta (Lepidoptera, Sphingidae) and its natural host Nicotiana attenuata. III. Fatty acid-amino acid conjugates in herbivore oral secretions are necessary and sufficient for herbivore-specific plant responses. Plant Physiol. 2001, 125, 711-717. 
198. War, A.R.; Paulraj, M.G.; Ahmad, T.; Buhroo, A.A.; Hussain, B.; Ignacimuthu, S.; Sharma, H.C. Mechanisms of plant defense against insect herbivores. Plant Signal. Behav. 2012, 7, 1306-1320. [CrossRef]

199. Louis, J.; Shah, J. Arabidopsis thaliana-Myzus persicae interaction: Shaping the understanding of plant defense against phloem-feeding aphids. Front. Plant Sci. 2013, 4, 213. [CrossRef]

200. Tian, D.; Peiffer, M.; Shoemaker, E.; Tooker, J.; Haubruge, E.; Francis, F.; Luthe, D.S.; Felton, G.W. Salivary glucose oxidase from caterpillars mediates the induction of rapid and delayed-induced defenses in the tomato plant. PLoS ONE 2012, 7, e36168. [CrossRef]

201. Consales, F.; Schweizer, F.; Erb, M.; Gouhier-Darimont, C.; Bodenhausen, N.; Bruessow, F.; Sobhy, I.; Reymond, P. Insect oral secretions suppress wound-induced responses in Arabidopsis. J. Exp. Bot. 2011, 63, 727-737. [CrossRef]

202. Eichenseer, H.; Mathews, M.; Powell, J.S.; Felton, G.W. Survey of a salivary effector in caterpillars: Glucose oxidase variation and correlation with host range. J. Chem. Ecol. 2010, 36, 885-897. [CrossRef]

203. Elzinga, D.A.; Jander, G. The role of protein effectors in plant-aphid interactions. Curr. Opin. Plant Biol. 2013, 16, 451-456. [CrossRef]

204. Jaouannet, M.; Rodriguez, P.A.; Thorpe, P.; Lenoir, C.J.; MacLeod, R.; Escudero-Martinez, C.; Bos, J.I. Plant immunity in plant-aphid interactions. Front. Plant Sci. 2014, 5, 663. [CrossRef]

205. Bos, J.I.; Prince, D.; Pitino, M.; Maffei, M.E.; Win, J.; Hogenhout, S.A. A functional genomics approach identifies candidate effectors from the aphid species Myzus persicae (green peach aphid). PLoS Genet. 2010, 6, e1001216. [CrossRef]

206. Rodriguez, P.A.; Stam, R.; Warbroek, T.; Bos, J.I. Mp10 and Mp42 from the aphid species Myzus persicae trigger plant defenses in Nicotiana benthamiana through different activities. Mol. Plant Microbe Interact. 2014, 27, 30-39. [CrossRef]

207. Schwartzberg, E.G.; Tumlinson, J.H. Aphid honeydew alters plant defence responses. Funct. Ecol. 2014, 28, 386-394. [CrossRef]

208. Sabri, A.; Vandermoten, S.; Leroy, P.D.; Haubruge, E.; Hance, T.; Thonart, P.; De Pauw, E.; Francis, F. Proteomic investigation of aphid honeydew reveals an unexpected diversity of proteins. PLoS ONE 2013, 8, e74656. [CrossRef]

209. Stavrinides, J.; McCloskey, J.K.; Ochman, H. Pea aphid as both host and vector for the phytopathogenic bacterium Pseudomonas syringae. Appl. Environ. Microbiol. 2009, 75, 2230-2235. [CrossRef]

210. Meziane, H.; Van Der Sluis, I.; Van Loon, L.C.; Höfte, M.; Bakker, P.A. Determinants of Pseudomonas putida WCS358 involved in inducing systemic resistance in plants. Mol. Plant Pathol. 2005, 6, 177-185. [CrossRef]

211. De Vleesschauwer, D.; Djavaheri, M.; Bakker, P.A.; Höfte, M. Pseudomonas fluorescens WCS374r-induced systemic resistance in rice against Magnaporthe oryzae is based on pseudobactin-mediated priming for a salicylic acid-repressible multifaceted defense response. Plant Physiol. 2008, 148, 1996-2012. [CrossRef]

212. Loper, J.E.; Buyer, J.S. Siderophores in microbial interactions on plant surfaces. Mol. Plant Microbe Interact. 1991, 4, 5-13. [CrossRef]

213. Budzikiewicz, H. Siderophores of the Pseudomonadaceae sensu stricto (fluorescent and non-fluorescent Pseudomonas spp.). In Progress in the Chemistry of Organic Natural Products; Springer: Vienna, Austria, 2004; pp. 81-237.

214. De Vleesschauwer, D.; Höfte, M. Rhizobacteria-induced systemic resistance. Adv. Bot. Res. 2009, 51, $223-281$.

215. Bakker, P.A.; Pieterse, C.M.; Van Loon, L. Induced systemic resistance by fluorescent Pseudomonas spp. Phytopathology 2007, 97, 239-243. [CrossRef] [PubMed]

216. Ran, L.; Li, Z.; Wu, G.; Van Loon, L.; Bakker, P.H. Induction of systemic resistance against bacterial wilt in Eucalyptus urophylla by fluorescent Pseudomonas spp. Eur. J. Plant Pathol. 2005, 113, 59-70. [CrossRef]

217. De Meyer, G.; Höfte, M. Salicylic acid produced by the rhizobacterium Pseudomonas aeruginosa 7NSK2 induces resistance to leaf infection by Botrytis cinerea on bean. Phytopathology 1997, 87, 588-593. [CrossRef] [PubMed]

218. De Meyer, G.; Audenaert, K.; Höfte, M. Pseudomonas aeruginosa 7NSK2-induced systemic resistance in tobacco depends on in planta salicylic acid accumulation but is not associated with PR1a expression. Eur. J. Plant Pathol. 1999, 105, 513-517. [CrossRef]

219. Ongena, M.; Jourdan, E.; Schäfer, M.; Kech, C.; Budzikiewicz, H.; Luxen, A.; Thonart, P. Isolation of an N-alkylated benzylamine derivative from Pseudomonas putida BTP1 as elicitor of induced systemic resistance in bean. Mol. Plant Microbe Interact. 2005, 18, 562-569. [CrossRef] 
220. Serino, L.; Reimmann, C.; Visca, P.; Beyeler, M.; Chiesa, V.; Haas, D. Biosynthesis of pyochelin and dihydroaeruginoic acid requires the iron-regulated pchDCBA operon in Pseudomonas aeruginosa. J. Bacteriol. 1997, 179, 248-257. [CrossRef]

221. Audenaert, K.; Pattery, T.; Cornelis, P.; Höfte, M. Induction of systemic resistance to Botrytis cinerea in tomato by Pseudomonas aeruginosa 7NSK2: Role of salicylic acid, pyochelin, and pyocyanin. Mol. Plant Microbe Interact. 2002, 15, 1147-1156. [CrossRef]

222. Verhagen, B.W.; Trotel-Aziz, P.; Couderchet, M.; Höfte, M.; Aziz, A. Pseudomonas spp.-induced systemic resistance to Botrytis cinerea is associated with induction and priming of defence responses in grapevine. J. Exp. Bot. 2009, 61, 249-260. [CrossRef]

223. Iavicoli, A.; Boutet, E.; Buchala, A.; Métraux, J.-P. Induced systemic resistance in Arabidopsis thaliana in response to root inoculation with Pseudomonas fluorescens CHA0. Mol. Plant Microbe Interact. 2003, 16, 851-858. [CrossRef]

224. Siddiqui, I.; Shaukat, S. Systemic resistance in tomato induced by biocontrol bacteria against the root-knot nematode, Meloidogyne javanica is independent of salicylic acid production. J. Phytopathol. 2004, 152, 48-54. [CrossRef]

225. Meyer, S.L.; Everts, K.L.; Gardener, B.M.; Masler, E.P.; Abdelnabby, H.M.; Skantar, A.M. Assessment of DAPG-producing Pseudomonas fluorescens for management of Meloidogyne incognita and Fusarium oxysporum on watermelon. J. Nematol. 2016, 48, 43-53. [CrossRef]

226. Tran, H.; Ficke, A.; Asiimwe, T.; Höfte, M.; Raaijmakers, J.M. Role of the cyclic lipopeptide massetolide A in biological control of Phytophthora infestans and in colonization of tomato plants by Pseudomonas fluorescens. New Phytol. 2007, 175, 731-742. [CrossRef]

227. Ongena, M.; Jourdan, E.; Adam, A.; Paquot, M.; Brans, A.; Joris, B.; Arpigny, J.L.; Thonart, P. Surfactin and fengycin lipopeptides of Bacillus subtilis as elicitors of induced systemic resistance in plants. Environ. Microbiol. 2007, 9, 1084-1090. [CrossRef] [PubMed]

228. Ipper, N.S.; Cho, S.; Lee, S.H.; Cho, J.M.; Hur, J.H.; Lim, C.K. Antiviral activity of the exopolysaccharide produced by Serratia sp. strain Gsm01 against Cucumber mosaic virus. J. Microbiol. Biotechnol. 2008, 18, $67-73$.

229. Schuhegger, R.; Ihring, A.; Gantner, S.; Bahnweg, G.; Knappe, C.; Vogg, G.; Hutzler, P.; Schmid, M.; Van Breusegem, F.; Eberl, L. Induction of systemic resistance in tomato by $N$-acyl-L-homoserine lactone-producing rhizosphere bacteria. Plant Cell Environ. 2006, 29, 909-918. [CrossRef]

230. Djonović, S.; Pozo, M.J.; Dangott, L.J.; Howell, C.R.; Kenerley, C.M. Sm1, a proteinaceous elicitor secreted by the biocontrol fungus Trichoderma virens induces plant defense responses and systemic resistance. Mol. Plant Microbe Interact. 2006, 19, 838-853. [CrossRef]

231. Viterbo, A.; Wiest, A.; Brotman, Y.; Chet, I.; Kenerley, C. The 18 mer peptaibols from Trichoderma virens elicit plant defence responses. Mol. Plant Pathol. 2007, 8, 737-746. [CrossRef]

232. Rippa, S.; Eid, M.; Formaggio, F.; Toniolo, C.; Béven, L. Hypersensitive-Like Response to the Pore-Former Peptaibol Alamethicin in Arabidopsis thaliana. ChemBioChem 2010, 11, 2042-2049. [CrossRef]

233. Vinale, F.; Sivasithamparam, K.; Ghisalberti, E.; Marra, R.; Barbetti, M.; Li, H.; Woo, S.; Lorito, M. A novel role for Trichoderma secondary metabolites in the interactions with plants. Physiol. Mol. Plant Pathol. 2008, 72, 80-86. [CrossRef]

234. Nürnberger, T.; Brunner, F.; Kemmerling, B.; Piater, L. Innate immunity in plants and animals: Striking similarities and obvious differences. Immunol. Rev. 2004, 198, 249-266. [CrossRef] [PubMed]

235. Iriti, M.; Varoni, E.M. Chitosan-induced antiviral activity and innate immunity in plants. Environ. Sci. Pollut. Res. 2015, 22, 2935-2944. [CrossRef] [PubMed]

236. Klarzynski, O.; Plesse, B.; Joubert, J.-M.; Yvin, J.-C.; Kopp, M.; Kloareg, B.; Fritig, B. Linear $\beta-1,3$ glucans are elicitors of defense responses in tobacco. Plant Physiol. 2000, 124, 1027-1038. [CrossRef] [PubMed]

237. Fesel, P.H.; Zuccaro, A. $\beta$-glucan: Crucial component of the fungal cell wall and elusive MAMP in plants. Fungal Genet. Biol. 2016, 90, 53-60. [CrossRef] [PubMed]

238. Chaliha, C.; Rugen, M.D.; Field, R.A.; Kalita, E. Glycans as modulators of plant defense against filamentous pathogens. Front. Plant Sci. 2018, 9, 928. [CrossRef] [PubMed]

239. Gullino, M.L.; Leroux, P.; Smith, C.M. Uses and challenges of novel compounds for plant disease control. Crop Prot. 2000, 19, 1-11. [CrossRef] 
240. Oostendorp, M.; Kunz, W.; Dietrich, B.; Staub, T. Induced disease resistance in plants by chemicals. Eur. J. Plant Pathol. 2001, 107, 19-28. [CrossRef]

241. Mayers, C.N.; Lee, K.-C.; Moore, C.A.; Wong, S.-M.; Carr, J.P. Salicylic acid-induced resistance to Cucumber mosaic virus in squash and Arabidopsis thaliana: Contrasting mechanisms of induction and antiviral action. Mol. Plant Microbe Interact. 2005, 18, 428-434. [CrossRef]

242. Hong, J.K.; Hwang, B.K.; Kim, C.H. Induction of local and systemic resistance to Colletotrichum coccodes in pepper plants by dl- $\beta$-amino-n-butyric acid. J. Phytopathol. 1999, 147, 193-198. [CrossRef]

243. Qian, Z.G.; Zhao, Z.J.; Xu, Y.; Qian, X.; Zhong, J.J. Novel chemically synthesized salicylate derivative as an effective elicitor for inducing the biosynthesis of plant secondary metabolites. Biotechnol. Prog. 2006, 22, 331-333. [CrossRef]

244. Sanjula, S.; Sohal, B. Foliar spray of Benzothiadiazole and salicylic acid on Brassica juncea var. RLM619 to combat Alternaria blight in field trials. Crop Improv. 2010, 37, 87-92.

245. Abdel-Monaim, M.F.; Ismail, M.E.; Morsy, K.M. Induction of systemic resistance of benzothiadiazole and humic acid in soybean plants against Fusarium wilt disease. Mycobiology 2011, 39, 290-298. [CrossRef] [PubMed]

246. Lee, J.; Klessig, D.F.; Nürnberger, T. A harpin binding site in tobacco plasma membranes mediates activation of the pathogenesis-related gene HIN1 independent of extracellular calcium but dependent on mitogen-activated protein kinase activity. Plant Cell 2001, 13, 1079-1093. [CrossRef] [PubMed]

247. Li, W.; Shao, M.; Zhong, W.; Yang, J.; Okada, K.; Yamane, H.; Zhang, L.; Wang, G.; Wang, D.; Xiao, S. Ectopic expression of Hrf1 enhances bacterial resistance via regulation of diterpene phytoalexins, silicon and reactive oxygen species burst in rice. PLoS ONE 2012, 7, e43914. [CrossRef] [PubMed]

248. Henry, G.; Thonart, P.; Ongena, M. PAMPs, MAMPs, DAMPs and others: An update on the diversity of plant immunity elicitors. BASE 2012, 16, 257-268.

249. Huang, C.J.; Tsay, J.F.; Chang, S.Y.; Yang, H.P.; Wu, W.S.; Chen, C.Y. Dimethyl disulfide is an induced systemic resistance elicitor produced by Bacillus cereus C1L. Pest Manag. Sci. 2012, 68, 1306-1310. [CrossRef] [PubMed]

250. Hahn, M.G.; Albersheim, P. Host-pathogen interactions: XIV. Isolation and partial characterization of an elicitor from yeast extract. Plant Physiol. 1978, 62, 107-111. [CrossRef]

251. Fu, Y.; Yin, H.; Wang, W.; Wang, M.; Zhang, H.; Zhao, X.; Du, Y. $\beta-1$, 3-Glucan with different degree of polymerization induced different defense responses in tobacco. Carbohydr. Polym. 2011, 86, 774-782. [CrossRef]

252. Falcón-Rodríguez, A.B.; Wégria, G.; Cabrera, J.-C. Exploiting plant innate immunity to protect crops against biotic stress: Chitosaccharides as natural and suitable candidates for this purpose. In New Perspectives in Plant Protection; InTech: London, UK, 2012.

253. Henriquez, M.A.; Wolski, E.A.; Molina, O.I.; Adam, L.R.; Andreu, A.B.; Daayf, F. Effects of glucans and eicosapentaenoic acid on differential regulation of phenylpropanoid and mevalonic pathways during potato response to Phytophthora infestans. Plant Physiol. Biochem. 2012, 60, 119-128. [CrossRef]

254. Laquitaine, L.; Gomès, E.; François, J.; Marchive, C.; Pascal, S.; Hamdi, S.; Atanassova, R.; Delrot, S.; Coutos-Thévenot, P. Molecular basis of ergosterol-induced protection of grape against Botrytis cinerea: Induction of type I LTP promoter activity, WRKY, and stilbene synthase gene expression. Mol. Plant Microbe Interact. 2006, 19, 1103-1112. [CrossRef]

255. Vatsa, P.; Chiltz, A.; Luini, E.; Vandelle, E.; Pugin, A.; Roblin, G. Cytosolic calcium rises and related events in ergosterol-treated Nicotiana cells. Plant Physiol. Biochem. 2011, 49, 764-773. [CrossRef] [PubMed]

256. Chen, M.; Zeng, H.; Qiu, D.; Guo, L.; Yang, X.; Shi, H.; Zhou, T.; Zhao, J. Purification and characterization of a novel hypersensitive response-inducing elicitor from Magnaporthe oryzae that triggers defense response in rice. PLOS ONE 2012, 7, e37654. [CrossRef]

257. Kulye, M.; Liu, H.; Zhang, Y.; Zeng, H.; Yang, X.; Qiu, D. Hrip1, a novel protein elicitor from necrotrophic fungus, Alternaria tenuissima, elicits cell death, expression of defence-related genes and systemic acquired resistance in tobacco. Plant Cell Environ. 2012, 35, 2104-2120. [CrossRef] [PubMed]

258. Khan, N.U.; Liu, M.; Yang, X.; Qiu, D. Fungal Elicitor MoHrip2 Induces Disease Resistance in Rice Leaves, Triggering Stress-Related Pathways. PLoS ONE 2016, 11, e0158112. [CrossRef] [PubMed]

259. Qiu, D.; Mao, J.; Yang, X.; Zeng, H. Expression of an elicitor-encoding gene from Magnaporthe grisea enhances resistance against blast disease in transgenic rice. Plant Cell Rep. 2009, 28, 925-933. [CrossRef] [PubMed] 
260. Peng, D.-H.; Qiu, D.-W.; Ruan, L.-F.; Zhou, C.-F.; Sun, M. Protein elicitor PemG1 from Magnaporthe grisea induces systemic acquired resistance (SAR) in plants. Mol. Plant Microbe Interact. 2011, 24, 1239-1246. [CrossRef] [PubMed]

261. Bailey, B.A.; Dean, J.F.; Anderson, J.D. An ethylene biosynthesis-inducing endoxylanase elicits electrolyte leakage and necrosis in Nicotiana tabacum cv xanthi leaves. Plant Physiol. 1990, 94, 1849-1854. [CrossRef]

262. Ron, M.; Kantety, R.; Martin, G.; Avidan, N.; Eshed, Y.; Zamir, D.; Avni, A. High-resolution linkage analysis and physical characterization of the EIX-responding locus in tomato. Theor. Appl. Genet. 2000, 100, 184-189. [CrossRef]

263. El Baz, F.K.; Aboul-Enein, A.M.; El-Baroty, G.S.; Youssef, A.; Abdel-Baky, H.H. Accumulation of antioxidant vitamins in Dunaliella salina. J. Biol. Sci. 2002, 2, 220-223.

264. Fuchs, Y.; Saxena, A.; Gamble, H.R.; Anderson, J.D. Ethylene biosynthesis-inducing protein from cellulysin is an endoxylanase. Plant Physiol. 1989, 89, 138-143. [CrossRef]

265. Scheer, J.M.; Ryan, C.A. The systemin receptor SR160 from Lycopersicon peruvianum is a member of the LRR receptor kinase family. Proc. Natl. Acad. Sci. USA 2002, 99, 9585-9590. [CrossRef] [PubMed]

266. Hou, S.; Wang, X.; Chen, D.; Yang, X.; Wang, M.; Turrà, D.; Di Pietro, A.; Zhang, W. The secreted peptide PIP1 amplifies immunity through receptor-like kinase 7. PLoS Pathog. 2014, 10, e1004331. [CrossRef] [PubMed]

267. Yamaguchi, Y.; Pearce, G.; Ryan, C.A. The cell surface leucine-rich repeat receptor for AtPep1, an endogenous peptide elicitor in Arabidopsis, is functional in transgenic tobacco cells. Proc. Natl. Acad. Sci. USA 2006, 103, 10104-10109. [CrossRef] [PubMed]

268. Yamaguchi, Y.; Huffaker, A.; Bryan, A.C.; Tax, F.E.; Ryan, C.A. PEPR2 is a second receptor for the Pep1 and Pep2 peptides and contributes to defense responses in Arabidopsis. Plant Cell 2010, 22, 508-522. [CrossRef] [PubMed]

269. Haruta, M.; Sabat, G.; Stecker, K.; Minkoff, B.B.; Sussman, M.R. A peptide hormone and its receptor protein kinase regulate plant cell expansion. Science 2014, 343, 408-411. [CrossRef] [PubMed]

270. Stegmann, M.; Monaghan, J.; Smakowska-Luzan, E.; Rovenich, H.; Lehner, A.; Holton, N.; Belkhadir, Y.; Zipfel, C. The receptor kinase FER is a RALF-regulated scaffold controlling plant immune signaling. Science 2017, 355, 287-289. [CrossRef] [PubMed]

271. Brutus, A.; Sicilia, F.; Macone, A.; Cervone, F.; De Lorenzo, G. A domain swap approach reveals a role of the plant wall-associated kinase 1 (WAK1) as a receptor of oligogalacturonides. Proc. Natl. Acad. Sci. USA 2010, 107, 9452-9457. [CrossRef]

272. Choi, J. Identification of a plant receptor for extracellular ATP (vol 343, pg 290, 2014). Science 2014, 343 , 730. [CrossRef]

273. Altenbach, D.; Robatzek, S. Pattern recognition receptors: From the cell surface to intracellular dynamics. Mol. Plant Microbe Interact. 2007, 20, 1031-1039. [CrossRef]

274. Kouzai, Y.; Mochizuki, S.; Nakajima, K.; Desaki, Y.; Hayafune, M.; Miyazaki, H.; Yokotani, N.; Ozawa, K.; Minami, E.; Kaku, H. Targeted gene disruption of OsCERK1 reveals its indispensable role in chitin perception and involvement in the peptidoglycan response and immunity in rice. Mol. Plant Microbe Interact. 2014, 27, 975-982. [CrossRef]

275. Shinya, T.; Motoyama, N.; Ikeda, A.; Wada, M.; Kamiya, K.; Hayafune, M.; Kaku, H.; Shibuya, N. Functional characterization of CEBiP and CERK1 homologs in Arabidopsis and rice reveals the presence of different chitin receptor systems in plants. Plant Cell Physiol. 2012, 53, 1696-1706. [CrossRef] [PubMed]

276. Shimizu, T.; Nakano, T.; Takamizawa, D.; Desaki, Y.; Ishii-Minami, N.; Nishizawa, Y.; Minami, E.; Okada, K.; Yamane, H.; Kaku, H. Two LysM receptor molecules, CEBiP and OsCERK1, cooperatively regulate chitin elicitor signaling in rice. Plant J. 2010, 64, 204-214. [CrossRef]

277. Squeglia, F.; Berisio, R.; Shibuya, N.; Kaku, H. Defense Against Pathogens: Structural Insights into the Mechanism of Chitin Induced Activation of Innate Immunity. Curr. Med. Chem. 2017, 24, 3980-3986. [CrossRef] [PubMed]

278. Squeglia, F.; Marchetti, R.; Ruggiero, A.; Lanzetta, R.; Marasco, D.; Dworkin, J.; Petoukhov, M.; Molinaro, A.; Berisio, R.; Silipo, A. Chemical basis of peptidoglycan discrimination by PrkC, a key kinase involved in bacterial resuscitation from dormancy. J. Am. Chem. Soc. 2011, 133, 20676-20679. [CrossRef] [PubMed]

279. Ruggiero, A.; Squeglia, F.; Marasco, D.; Marchetti, R.; Molinaro, A.; Berisio, R. X-ray structural studies of the entire extracellular region of the serine/threonine kinase PrkC from Staphylococcus aureus. Biochem. J. 2011, 435, 33-41. [CrossRef] 
280. Ruggiero, A.; De Simone, P.; Smaldone, G.; Squeglia, F.; Berisio, R. Bacterial cell division regulation by Ser/Thr kinases: A structural perspective. Curr. Protein Pept. Sci. 2012, 13, 756-766. [CrossRef]

281. Kouzai, Y.; Nakajima, K.; Hayafune, M.; Ozawa, K.; Kaku, H.; Shibuya, N.; Minami, E.; Nishizawa, Y. CEBiP is the major chitin oligomer-binding protein in rice and plays a main role in the perception of chitin oligomers. Plant Mol. Biol. 2014, 84, 519-528. [CrossRef]

282. Mentlak, T.A.; Kombrink, A.; Shinya, T.; Ryder, L.S.; Otomo, I.; Saitoh, H.; Terauchi, R.; Nishizawa, Y.; Shibuya, N.; Thomma, B.P. Effector-mediated suppression of chitin-triggered immunity by Magnaporthe oryzae is necessary for rice blast disease. Plant Cell 2012, 24, 322-335. [CrossRef]

283. Enkerli, J.; Felix, G.; Boller, T. The enzymatic activity of fungal xylanase is not necessary for its elicitor activity. Plant Physiol. 1999, 121, 391-398. [CrossRef]

284. Furman-Matarasso, N.; Cohen, E.; Du, Q.; Chejanovsky, N.; Hanania, U.; Avni, A. A point mutation in the ethylene-inducing xylanase elicitor inhibits the $\beta$-1-4-endoxylanase activity but not the elicitation activity. Plant Physiol. 1999, 121, 345-352. [CrossRef]

285. Rotblat, B.; Enshell-Seijffers, D.; Gershoni, J.M.; Schuster, S.; Avni, A. Identification of an essential component of the elicitation active site of the EIX protein elicitor. Plant J. 2002, 32, 1049-1055. [CrossRef] [PubMed]

286. Hanania, U.; Avni, A. High-affinity binding site for ethylene-inducing xylanase elicitor on Nicotiana tabacum membranes. Plant J. 1997, 12, 113-120. [CrossRef]

287. Bar, M.; Avni, A. EHD2 inhibits ligand-induced endocytosis and signaling of the leucine-rich repeat receptor-like protein LeEix2. Plant J. 2009, 59, 600-611. [CrossRef] [PubMed]

288. Willmann, R.; Lajunen, H.M.; Erbs, G.; Newman, M.-A.; Kolb, D.; Tsuda, K.; Katagiri, F.; Fliegmann, J.; Bono, J.-J.; Cullimore, J.V. Arabidopsis lysin-motif proteins LYM1 LYM3 CERK1 mediate bacterial peptidoglycan sensing and immunity to bacterial infection. Proc. Natl. Acad. Sci. USA 2011, 108, 19824-19829. [CrossRef] [PubMed]

289. Ao, Y.; Li, Z.; Feng, D.; Xiong, F.; Liu, J.; Li, J.F.; Wang, M.; Wang, J.; Liu, B.; Wang, H.B. Os CERK 1 and Os RLCK 176 play important roles in peptidoglycan and chitin signaling in rice innate immunity. Plant $J$. 2014, 80, 1072-1084. [CrossRef] [PubMed]

290. Gimenez-Ibanez, S.; Hann, D.R.; Ntoukakis, V.; Petutschnig, E.; Lipka, V.; Rathjen, J.P. AvrPtoB targets the LysM receptor kinase CERK1 to promote bacterial virulence on plants. Curr. Biol. 2009, 19, 423-429. [CrossRef] [PubMed]

291. Yamaguchi, K.; Yamada, K.; Ishikawa, K.; Yoshimura, S.; Hayashi, N.; Uchihashi, K.; Ishihama, N.; Kishi-Kaboshi, M.; Takahashi, A.; Tsuge, S. A receptor-like cytoplasmic kinase targeted by a plant pathogen effector is directly phosphorylated by the chitin receptor and mediates rice immunity. Cell Host Microbe 2013, 13, 347-357. [CrossRef]

292. Kunkel, B.N.; Bent, A.F.; Dahlbeck, D.; Innes, R.W.; Staskawicz, B.J. RPS2, an Arabidopsis disease resistance locus specifying recognition of Pseudomonas syringae strains expressing the avirulence gene avrRpt2. Plant Cell 1993, 5, 865-875.

293. Yu, G.-L.; Katagiri, F.; Ausubel, F.M. Arabidopsis mutations at the RPS2 locus result in loss of resistance to Pseudomonas syringae strains expressing the avirulence gene avrRpt2. Mol. Plant Microbe Interact. 1993, 6, 434. [CrossRef]

294. Martin, G.B.; Brommonschenkel, S.H.; Chunwongse, J.; Frary, A.; Ganal, M.W.; Spivey, R.; Wu, T.; Earle, E.D.; Tanksley, S.D. Map-based cloning of a protein kinase gene conferring disease resistance in tomato. Science 1993, 262, 1432-1436. [CrossRef]

295. Song, W.-Y.; Wang, G.-L.; Chen, L.-L.; Kim, H.-S.; Pi, L.-Y.; Holsten, T.; Gardner, J.; Wang, B.; Zhai, W.-X.; Zhu, L.-H. A receptor kinase-like protein encoded by the rice disease resistance gene, Xa21. Science 1995, 270, 1804-1806. [CrossRef] [PubMed]

296. Kawchuk, L.; Hachey, J.; Lynch, D. Development of sequence characterized DNA markers linked to a dominant verticillium wilt resistance gene in tomato. Genome 1998, 41, 91-95. [CrossRef] [PubMed]

297. Dardick, C.; Ronald, P. Plant and animal pathogen recognition receptors signal through non-RD kinases. PLoS Pathog. 2006, 2, e2. [CrossRef] [PubMed]

298. Ronald, P.C.; Albano, B.; Tabien, R.; Abenes, L.; Wu, K.-s.; McCouch, S.; Tanksley, S.D. Genetic and physical analysis of the rice bacterial blight disease resistance locus, Xa21. Mol. Gen. Genet. MGG 1992, 236, 113-120. [CrossRef] 
299. Poltorak, A.; He, X.; Smirnova, L.; Liu, M.; Huffel, C.; Du, X.; Birdwell, D.; Alejos ESilva, M.; Galanos, C.; Freudenberg, M.A.; et al. Defective LPS signaling in C3H/HeJ and C57BL/10ScCr mice: Mutations in Tlr4 gene. Science 1998, 597, 2085-2088. [CrossRef]

300. Hanks, S.K.; Quinn, A.M. Protein kinase catalytic domain sequence database: Identification of conserved features of primary structure and classification of family members. In Methods in Enzymology; Elsevier Inc.: Amsterdam, The Netherlands, 1991; Volume 200, pp. 38-62.

301. Dixon, M.S.; Jones, D.A.; Keddie, J.S.; Thomas, C.M.; Harrison, K.; Jones, J.D. The tomato Cf-2 disease resistance locus comprises two functional genes encoding leucine-rich repeat proteins. Cell 1996, 84, 451-459. [CrossRef]

302. Hashimoto, C.; Hudson, K.L.; Anderson, K.V. The Toll gene of Drosophila, required for dorsal-ventral embryonic polarity, appears to encode a transmembrane protein. Cell 1988, 52, 269-279. [CrossRef]

303. Zeng, W.; He, S.Y. A prominent role of the flagellin receptor FLAGELLIN-SENSING2 in mediating stomatal response to Pseudomonas syringae pv tomato DC3000 in Arabidopsis. Plant Physiol. 2010, 153, 1188-1198. [CrossRef]

304. Zamioudis, C.; Pieterse, C.M. Modulation of host immunity by beneficial microbes. Mol. Plant Microbe Interact. 2012, 25, 139-150. [CrossRef]

305. Howe, G.A.; Jander, G. Plant immunity to insect herbivores. Ann. Rev. Plant Biol. 2008, 59, 41-66. [CrossRef]

306. Arimura, G.-I.; Ozawa, R.; Maffei, M.E. Recent advances in plant early signaling in response to herbivory. Int. J. Mol. Sci. 2011, 12, 3723-3739. [CrossRef]

307. Thaler, J.S.; Humphrey, P.T.; Whiteman, N.K. Evolution of jasmonate and salicylate signal crosstalk. Trends Plant Sci. 2012, 17, 260-270. [CrossRef]

308. Basu, S.; Varsani, S.; Louis, J. Altering plant defenses: Herbivore-associated molecular patterns and effector Arsenal of chewing herbivores. Mol. Plant Microbe Interact. 2017, 31, 13-21. [CrossRef]

309. Pieterse, C.M.; Van der Does, D.; Zamioudis, C.; Leon-Reyes, A.; Van Wees, S.C. Hormonal modulation of plant immunity. Ann. Rev. Cell Dev. Biol. 2012, 28, 489-521. [CrossRef] [PubMed]

310. Yamaguchi, Y.; Huffaker, A. Endogenous peptide elicitors in higher plants. Curr. Opin. Plant Biol. 2011, 14, 351-357. [CrossRef] [PubMed]

311. Bartels, S.; Boller, T. Quo vadis, Pep? Plant elicitor peptides at the crossroads of immunity, stress, and development. J. Exp. Bot. 2015, 66, 5183-5193. [CrossRef] [PubMed]

312. Pearce, G.; Bhattacharya, R.; Chen, Y.-C.; Barona, G.; Yamaguchi, Y.; Ryan, C.A. Isolation and characterization of hydroxyproline-rich glycopeptide signals in black nightshade leaves. Plant Physiol. 2009, 150, 1422-1433. [CrossRef] [PubMed]

313. Beloshistov, R.E.; Dreizler, K.; Galiullina, R.A.; Tuzhikov, A.I.; Serebryakova, M.V.; Reichardt, S.; Shaw, J.; Taliansky, M.E.; Pfannstiel, J.; Chichkova, N.V. Phytaspase-mediated precursor processing and maturation of the wound hormone systemin. New Phytol. 2018, 218, 1167-1178. [CrossRef] [PubMed]

314. Chen, Y.-C.; Siems, W.F.; Pearce, G.; Ryan, C.A. Six peptide wound signals derived from a single precursor protein in Ipomoea batatas leaves activate the expression of the defense gene sporamin. J. Biol. Chem. 2008, 283, 11469-11476. [CrossRef] [PubMed]

315. Huffaker, A.; Pearce, G.; Veyrat, N.; Erb, M.; Turlings, T.C.; Sartor, R.; Shen, Z.; Briggs, S.P.; Vaughan, M.M.; Alborn, H.T. Plant elicitor peptides are conserved signals regulating direct and indirect antiherbivore defense. Proc. Natl. Acad. Sci. USA 2013, 110, 5707-5712. [CrossRef]

316. Tintor, N.; Ross, A.; Kanehara, K.; Yamada, K.; Fan, L.; Kemmerling, B.; Nürnberger, T.; Tsuda, K.; Saijo, Y. Layered pattern receptor signaling via ethylene and endogenous elicitor peptides during Arabidopsis immunity to bacterial infection. Proc. Natl. Acad. Sci. USA 2013, 110, 6211-6216. [CrossRef] [PubMed]

317. Ross, A.; Yamada, K.; Hiruma, K.; Yamashita-Yamada, M.; Lu, X.; Takano, Y.; Tsuda, K.; Saijo, Y. The Arabidopsis PEPR pathway couples local and systemic plant immunity. EMBO J. 2014, 33, 62-75. [CrossRef] [PubMed]

318. Lee, G.; Joo, Y.; Kim, S.G.; Baldwin, I.T. What happens in the pith stays in the pith: Tissue-localized defense responses facilitate chemical niche differentiation between two spatially separated herbivores. Plant J. 2017, 92, 414-425. [CrossRef] [PubMed]

319. Yamada, K.; Yamashita-Yamada, M.; Hirase, T.; Fujiwara, T.; Tsuda, K.; Hiruma, K.; Saijo, Y. Danger peptide receptor signaling in plants ensures basal immunity upon pathogen-induced depletion of BAK1. EMBO J. 2016, 35, 46-61. [CrossRef] [PubMed] 
320. Lori, M.; Van Verk, M.C.; Hander, T.; Schatowitz, H.; Klauser, D.; Flury, P.; Gehring, C.A.; Boller, T.; Bartels, S. Evolutionary divergence of the plant elicitor peptides (Peps) and their receptors: Interfamily incompatibility of perception but compatibility of downstream signalling. J. Exp. Bot. 2015, 66, 5315-5325. [CrossRef]

321. Sun, X.; Cao, Y.; Yang, Z.; Xu, C.; Li, X.; Wang, S.; Zhang, Q. Xa26, a gene conferring resistance to Xanthomonas oryzae pv. oryzae in rice, encodes an LRR receptor kinase-like protein. Plant J. 2004, 37, 517-527. [CrossRef]

322. Nishimura, R.; Hayashi, M.; Wu, G.-J.; Kouchi, H.; Imaizumi-Anraku, H.; Murakami, Y.; Kawasaki, S.; Akao, S.; Ohmori, M.; Nagasawa, M. HAR1 mediates systemic regulation of symbiotic organ development. Nature 2002, 420, 426-429. [CrossRef]

323. Jones, D.A.; Thomas, C.M.; Hammond-Kosack, K.E.; Balint-Kurti, P.J.; Jones, J. Isolation of the tomato Cf-9 gene for resistance to Cladosporium fulvum by transposon tagging. Science 1994, 266, 789-793. [CrossRef]

324. Wang, L.; Einig, E.; Almeida-Trapp, M.; Albert, M.; Fliegmann, J.; Mithöfer, A.; Kalbacher, H.; Felix, G. The systemin receptor SYR1 enhances resistance of tomato against herbivorous insects. Nat. Plants 2018, 4, 152-156. [CrossRef]

325. Wang, L.; Albert, M.; Einig, E.; Fürst, U.; Krust, D.; Felix, G. The pattern-recognition receptor CORE of Solanaceae detects bacterial cold-shock protein. Nat. Plants 2016, 2, 16185. [CrossRef]

326. Saur, I.M.; Kadota, Y.; Sklenar, J.; Holton, N.J.; Smakowska, E.; Belkhadir, Y.; Zipfel, C.; Rathjen, J.P. NbCSPR underlies age-dependent immune responses to bacterial cold shock protein in Nicotiana benthamiana. Proc. Natl. Acad. Sci. USA 2016, 113, 3389-3394. [CrossRef]

327. Ranf, S.; Gisch, N.; Schäffer, M.; Illig, T.; Westphal, L.; Knirel, Y.A.; Sánchez-Carballo, P.M.; Zähringer, U.; Hückelhoven, R.; Lee, J. A lectin S-domain receptor kinase mediates lipopolysaccharide sensing in Arabidopsis thaliana. Nat. Immunol. 2015, 16, 426-433. [CrossRef] [PubMed]

328. Albert, I.; Böhm, H.; Albert, M.; Feiler, C.E.; Imkampe, J.; Wallmeroth, N.; Brancato, C.; Raaymakers, T.M.; Oome, S.; Zhang, H. An RLP23-SOBIR1-BAK1 complex mediates NLP-triggered immunity. Nat. Plants 2015, 1, 15140. [CrossRef] [PubMed]

329. Zhang, L.; Kars, I.; Essenstam, B.; Liebrand, T.W.; Wagemakers, L.; Elberse, J.; Tagkalaki, P.; Tjoitang, D.; van den Ackerveken, G.; van Kan, J.A. Fungal endopolygalacturonases are recognized as microbe-associated molecular patterns by the Arabidopsis receptor-like protein RESPONSIVENESS TO BOTRYTIS POLYGALACTURONASES1. Plant Physiol. 2014, 164, 352-364. [CrossRef]

330. Faulkner, C.; Petutschnig, E.; Benitez-Alfonso, Y.; Beck, M.; Robatzek, S.; Lipka, V.; Maule, A.J. LYM2-dependent chitin perception limits molecular flux via plasmodesmata. Proc. Natl. Acad. Sci. USA 2013, 110, 9166-9170. [CrossRef]

331. Catanzariti, A.M.; Lim, G.T.; Jones, D.A. The tomato I-3 gene: A novel gene for resistance to Fusarium wilt disease. New Phytol. 2015, 207, 106-118. [CrossRef]

332. Catanzariti, A.M.; Do, H.T.; Bru, P.; de Sain, M.; Thatcher, L.F.; Rep, M.; Jones, D.A. The tomato I gene for Fusarium wilt resistance encodes an atypical leucine-rich repeat receptor-like protein whose function is nevertheless dependent on SOBIR 1 and SERK 3/BAK 1. Plant J. 2017, 89, 1195-1209. [CrossRef]

333. Zhang, W.; Fraiture, M.; Kolb, D.; Löffelhardt, B.; Desaki, Y.; Boutrot, F.F.; Tör, M.; Zipfel, C.; Gust, A.A.; Brunner, F. Arabidopsis receptor-like protein30 and receptor-like kinase suppressor of BIR1-1/EVERSHED mediate innate immunity to necrotrophic fungi. Plant Cell 2013, 25, 4227-4241. [CrossRef]

334. Jehle, A.K.; Lipschis, M.; Albert, M.; Fallahzadeh-Mamaghani, V.; Fürst, U.; Mueller, K.; Felix, G. The receptor-like protein ReMAX of Arabidopsis detects the microbe-associated molecular pattern eMax from Xanthomonas. Plant Cell 2013, 25, 2330-2340. [CrossRef]

335. Cao, Y.; Liang, Y.; Tanaka, K.; Nguyen, C.T.; Jedrzejczak, R.P.; Joachimiak, A.; Stacey, G. The kinase LYK5 is a major chitin receptor in Arabidopsis and forms a chitin-induced complex with related kinase CERK1. eLife 2014, 3, e03766. [CrossRef]

336. Larkan, N.; Lydiate, D.; Parkin, I.; Nelson, M.; Epp, D.; Cowling, W.; Rimmer, S.; Borhan, M. The Brassica napus blackleg resistance gene LepR3 encodes a receptor-like protein triggered by the Leptosphaeria maculans effector AVRLM1. New Phytol. 2013, 197, 595-605. [CrossRef]

337. Larkan, N.J.; Ma, L.; Borhan, M.H. The B rassica napus receptor-like protein RLM 2 is encoded by a second allele of the L ep R 3/R lm2 blackleg resistance locus. Plant Biotechnol. J. 2015, 13, 983-992. [CrossRef] [PubMed] 
338. Rooney, H.C.; van't Klooster, J.W.; van der Hoorn, R.A.; Joosten, M.H.; Jones, J.D.; de Wit, P.J. Cladosporium Avr2 inhibits tomato Rcr3 protease required for Cf-2-dependent disease resistance. Science 2005, 308, 1783-1786. [CrossRef] [PubMed]

339. Dixon, M.S.; Hatzixanthis, K.; Jones, D.A.; Harrison, K.; Jones, J.D. The tomato Cf-5 disease resistance gene and six homologs show pronounced allelic variation in leucine-rich repeat copy number. Plant Cell 1998, 10, 1915-1925. [CrossRef] [PubMed]

340. Thomas, C.M.; Jones, D.A.; Parniske, M.; Harrison, K.; Balint-Kurti, P.J.; Hatzixanthis, K.; Jones, J. Characterization of the tomato Cf-4 gene for resistance to Cladosporium fulvum identifies sequences that determine recognitional specificity in Cf-4 and Cf-9. Plant Cell 1997, 9, 2209-2224. [PubMed]

341. Weinberger, F.; Friedlander, M.; Hoppe, H.G. Oligoagars elicit a physiological response in Gracilaria conferta (Rhodophyta). J. Phycol. 1999, 35, 747-755. [CrossRef]

342. Jourdan, E.; Henry, G.; Duby, F.; Dommes, J.; Barthelemy, J.-P.; Thonart, P.; Ongena, M. Insights into the defense-related events occurring in plant cells following perception of surfactin-type lipopeptide from Bacillus subtilis. Mol. Plant Microbe Interact. 2009, 22, 456-468. [CrossRef]

343. Conrath, U. Molecular aspects of defence priming. Trends Plant Sci. 2011, 16, 524-531. [CrossRef]

344. Fliegmann, J.; Mithöfer, A.; Wanner, G.; Ebel, J. An ancient enzyme domain hidden in the putative $\beta$-glucan elicitor receptor of soybean may play an active part in the perception of pathogen-associated molecular patterns during broad host resistance. J. Biol. Chem. 2004, 279, 1132-1140. [CrossRef]

345. Kunze, G.; Zipfel, C.; Robatzek, S.; Niehaus, K.; Boller, T.; Felix, G. The N terminus of bacterial elongation factor Tu elicits innate immunity in Arabidopsis plants. Plant Cell 2004, 16, 3496-3507. [CrossRef]

346. Chinchilla, D.; Bauer, Z.; Regenass, M.; Boller, T.; Felix, G. The Arabidopsis receptor kinase FLS2 binds flg22 and determines the specificity of flagellin perception. Plant Cell 2006, 18, 465-476. [CrossRef] [PubMed]

(C) 2020 by the authors. Licensee MDPI, Basel, Switzerland. This article is an open access article distributed under the terms and conditions of the Creative Commons Attribution (CC BY) license (http://creativecommons.org/licenses/by/4.0/). 